\title{
Climate-induced Boreal Forest Change: Predictions versus Current Observations
}

\section{Amber J. Soja ${ }^{1^{*}}$, Nadezda M. Tchebakova ${ }^{2}$, Nancy H. F. French ${ }^{3}$, Michael D. Flannigan $^{4}$, Herman. H. Shugart ${ }^{5}$, Brian J. Stocks ${ }^{4}$, Anatoly I. Sukhinin ${ }^{2}$, E.I. Parfenova $^{2}$, F. Stuart Chapin $\mathrm{III}^{5}$ and Paul W. Stackhouse Jr. ${ }^{6}$}

\author{
${ }^{1}$ National Institute of Aerospace \\ Resident at NASA Langley Research Center
}

21 Langley Boulevard, Mail Stop 420, Hampton, VA 23681-2199, United States

${ }^{2}$ Russian Academy of Sciences

Sukachev Institute of Forestry, 660036 Krasnojarsk, Siberia, Russia

${ }^{3}$ Altarum Institute (formerly ERIM)

PO Box 134001, Ann Arbor, MI 48113-4001, United States

${ }^{4}$ Canadian Forest Service

1219 Queen Street East, Sault Ste. Marie, Ontario P6A, 2E5 Canada

${ }^{5}$ Institute of Arctic Biology, University of Alaska Fairbanks,

Fairbanks, AK, 99775, United States

${ }^{6}$ NASA Langley Research Center

21 Langley Boulevard, Mail Stop 420, Hampton, VA 23681-2199, United States

* Corresponding author: Amber J. Soja, office (757) 864-5603, fax (757) 864-7996

a.j.soja@larc.nasa.gov 
Abstract: For about three decades, there have been many predictions of the potential ecological response in boreal regions to the currently warmer conditions. In essence, a widespread, naturally occurring experiment has been conducted over time. In this paper, we describe previously modeled predictions of ecological change in boreal Alaska, Canada and Russia, and then we investigate potential evidence of current climate-induced change. For instance, ecological models have suggested that warming will induce the northern and upslope migration of the treeline and an alteration in the current mosaic structure of boreal forests. We present evidence of the migration of keystone ecosystems in the upland and lowland treeline of mountainous regions across southern Siberia. Ecological models have also predicted a moisture-stress-related dieback in white spruce trees in Alaska, and current investigations show that as temperatures increase, white spruce tree growth is declining. Additionally, it was suggested that increases in infestation and wildfire disturbance would be catalysts that precipitate the alteration of the current mosaic forest composition. In Siberia, five of the last seven years have resulted in extreme fire seasons, and extreme fire years have also been more frequent in both Alaska and Canada. In addition, Alaska has experienced extreme and geographically expansive multi-year outbreaks of the spruce beetle, which had been previously limited by the cold, moist environment. We suggest that there is substantial evidence throughout the circumboreal region to conclude that the biosphere within the boreal terrestrial environment has already responded to the transient effects of climate change. Additionally, temperature increases and warming-induced change are progressing faster than had been predicted in some regions, suggesting a potential non-linear rapid response to changes in climate, as opposed to the predicted slow linear response to climate change. 
Keywords: Climate change evidence, fire, infestation disturbance, treeline progression, boreal, montane.

\subsection{Introduction}

The boreal forest covers in excess of 1.2 billion hectares (B ha), spanning North America and Eurasia (Baumgartner, 1979; Stocks and Lynham, 1996). Roughly delineated by the $13^{\circ} \mathrm{C}$ mean July isotherm in the north and the $18^{\circ} \mathrm{C}$ mean July isotherm in the south, the boreal zone is typically situated between 45 and 70 degrees north latitude (Larsen, 1980). Two-thirds of the area of the boreal forest is located in Eurasia, and the remaining third is located primarily in Canada and Alaska (Hare and Ritchie, 1972). The boreal forest is floristically simple and consists of hardy genera of larch (Larix), pine (Pinus), spruce (Picea), and fir (Abies) interspersed with deciduous hardwoods of birch (Betula), aspen (Populus), willow (Salix) and alder (Alnus). Despite this relative simplicity, boreal forest composition results from a complex interaction between climate, solar radiation, topography, geology, nutrient availability, soil moisture, soil temperature, permafrost, depth of forest floor organic layer, ecology of species, forest fires and infestations (Heinselman, 1978; Viereck and Schandelmeier, 1980; West et al., 1981; Bonan, 1989a; Bonan and Shugart, 1989). This unique cold weather interaction creates the conditions necessary for boreal regions to store the largest reservoir of global terrestrial carbon (30-35\%), primarily held in the organic soils of the forest floor (Apps et al., 1993; McGuire et al., 1995; Zoltai and Martikainen, 1996; Alexeyev and Birdsey, 1998).

It is generally accepted that mean global temperatures are increasing and that the largest temperature increases from climate change are currently found in the Northern Hemisphere upper latitudes, where the boreal forest resides (Figure 1) (Hansen et al., 1996; 
Balling et al., 1998; Serreze et al., 2000; IPCC, 2001). Additionally, the Intergovernmental Panel on Climate Change (IPCC) recently released the Second and Third Assessment Reports, which state "the balance of evidence suggests a discernable human influence on global climate" (IPCC, 2001). Moreover, paleoclimate analysis of the Northern Hemisphere indicates that $20^{\text {th }}$ century warming is likely to have been the largest of any century within the last 1000 years (Folland et al., 2001). Additionally, the 1990s are likely to have been the warmest decade and 1998 the warmest year in the millennium, which is not consistent with long-term astronomical forcings (Mann et al., 1999).

Future climate scenarios predict that the largest temperature increases from climate change will be in the Northern Hemisphere upper latitudes (Budyko et al., 1991; IPCC, 2001). Specifically, Atmosphere-Ocean General Circulation Models (AOGCM) are in agreement that winter warming across the circumboreal region will be in excess of $40 \%$ above the global mean in 2100, which equates to 1.3 to $6.3^{\circ} \mathrm{C}$ (IPCC, 2001; ACIA, 2004). Summer warming in Northern Eurasia is predicted to exceed $40 \%$ of the global mean, and summer warming in the boreal regions of Europe and Canada is predicted to be greater than the global mean. In Alaska, there is disagreement concerning the magnitude of predicted summer warming. Increases in precipitation are expected in Northern Eurasia, Alaska, and Canada, particularly during the winter season, which is consistent with current trends as shown in Figure 1. However, several authors have suggested that increases in precipitation throughout much of the boreal region will likely be offset with increases in evapotranspiration (Stocks et al., 2000; Groisman et al., in press).

Place figure 1 about here. 
For several decades, theories and models have been used to assess and predict the potential ecological effects of climate change in boreal regions. Bonan et al. $(1992 ; 1995)$ suggested that climate-induced warming would result in boreal forest expansion, which would decrease snow-covered land and cause further albedo-induced warming. Alternatively, several authors have suggested that grasslands and temperate forests would expand northward and boreal forest expansion would be limited by poor soils, permafrost, and the time required to migrate, resulting in decreases in boreal forest (Rizzo and Wilken, 1992; Smith and Shugart, 1993b). Predictive models have often been criticized because equilibrium results can only be compared to a reality may be 100 years in the future. However, the transient effects of climate change have also been a topic of discourse, and corollary research has resulted in numerous peer-reviewed publications. For example, Smith and Shugart (1993b; 1993a) found that even though the equilibrium analysis suggests a net increase in potential terrestrial carbon stored, the transient response results in increases of atmospheric $\mathrm{CO}_{2}$ of up to a third of the present level, which would enhance warming.

After decades of theory-based projections and numerical model-based predictions, we have come to a time where it is prudent to compare our predictions of the transient effects of climate change with the climate-induced changes that are currently evident in our environs. Because boreal and arctic ecosystems lie at latitudes where intense climate-induced change is expected to first occur, it is essential to examine these regions for initial indications of climate-induced change. As it turns out, many of the transient predictions of boreal ecosystem change are already occurring, and this benchmark validation of the original suppositions and model results provides credence for the fundamental theory and future predictions. Additionally, much of the climate-induced change is occurring faster than 
originally thought, suggesting potential non-linear rapid change, as opposed to a slow linear progression of change.

The boreal ecozone is a keystone region where both its sensitivity to change and its size make it likely to affect the global climate system (Figure 2). Boreal zones have the potential to influence climate: (1) by modifying the global carbon budget by altering the sequestration and release of carbon (releasing stored pools of carbon); (2) by altering the radiation budget through emissions from fire and albedo change (land use change, burned landscapes and species composition change); and (3) by modifying the moisture balance. (Walter, 1979; Van Cleve and Viereck, 1983; Kurz et al., 1995; Harden et al., 2000; Kasischke and Stocks, 2000; Dale et al., 2001; French, 2002; Soja et al., 2004a; Balzter et al., 2005).

Place figure 2 about here.

\subsection{Objectives}

The purpose of this paper is not to serve as a review, but rather to assess the current state of boreal ecosystems as they relate to previous predictions of climate-induced ecological change. Predicted initial ecological indicators of climate change are: (1) an overall increase in fire regimes (frequency, severity, area burned, extent and longer fire seasons); (2) an increase in infestation (frequency, duration and extent); (3) an altered treeline; and (4) standand landscape-scale alteration of the mosaic composition of forests (age, structure and species composition) (Greenbank, 1963; Mattson and Haack, 1987; Clark, 1988; Bonan, 1989b;

Overpeck et al., 1990; Flannigan and Van Wagner, 1991; Bonan et al., 1995; Stocks et al., 1998; Fleming et al., 2002). The geographic focus of this work is on North America and 
Russia, and the major areas of concentration are wildfire, vegetation change, and infestation in Alaska.

The subjects we have chosen to circumvent may be equally or more significant, however the focus of this paper is on the regions and topics where models have predicted change and where this change has been documented. For instance, the effects of climate change on permafrost in boreal regions (and other regions) are substantial and welldocumented (Jorgenson et al., 2001; Anisimov and Belolutskaya, 2002; Payette et al., 2004; Camill, 2005), however these discussions are beyond the scope of this paper. Secondly, even though insect disturbance is extensive across Siberia and Canada, the authors are not aware of investigations that demonstrate these outbreaks are beyond the range of "normal" cycles

(Figure 3). However, investigations have suggested that insect outbreaks will increase under future warmer conditions (Neuvonen et al., 1999; Volney and Fleming, 2001; Candau and Fleming, 2005), and anecdotally Logan et al. (2003) noted pine beetle outbreaks were occurring further north in British Columbia than had been previously recorded. Additionally, Fleming (2000) highlighted the uncertainties in estimating changes in patterns of infestation (i.e. population-wide genetic change) and showed that wildfire is likely to increase 3-9 years after spruce budworm outbreaks (Fleming et al., 2002).

Place figure 3 about here.

\subsection{Discussion of climate-induced predictions and current landscape dynamics}

\subsubsection{Wildfire as a catalyst for change in North America and Russia}

Wildfire is an integral component of boreal landscapes and is widely recognized throughout the circumboreal zone as a dominant driver of ecological processes (Chudnikov, 1931; Tumel, 1939; Lutz, 1956; Rowe and Scotter, 1973; Van Cleve and Viereck, 1981; 
MacLean et al., 1983; Kasischke and Stocks, 2000; Chapin et al., 2006a). By resolving the beginning and end of successional processes, wildfire maintains age structure, species composition, and the floristic diversity of boreal forest (Zackrisson, 1977; Van Wagner, 1978; Heinselman, 1981; Antonovski et al., 1992). In a recent paper, Weber and Flannigan (1997) highlighted the significance of fire in boreal regions when they wrote "An altered fire regime may be more important than the direct effects of climate change in forcing or facilitating species distribution changes, migration, substitution, and extinction."

Even though wildfire acts as a disturbing agent that maintains the current stability and mosaic structure of boreal ecosystems in a landscape-scale steady-state system (Loucks, 1970; Furyaev and Kireev, 1979; Viereck and Schandelmeier, 1980; Shugart et al., 1991), climate, both means and extremes, holds the ultimate key to altering boreal ecosystems. Climate manifests itself in terms of temperature and precipitation, which are primary factors in determining succession and the distribution of forest ecosystems along gradients in boreal regions (Shugart et al., 2000). Climate also has the potential to affect boreal fire regimes by altering species composition, fire ignitions from lightning and the weather conditions conducive to fire. Wildfire is a catalyst that serves two basic purposes in boreal forests: (1) a mechanism to maintain stability and diversity with the climate and; (2) a mechanism by which forests move more rapidly toward equilibrium with climate.

General agreement exists that under current climate change scenarios, fire frequency and area burned in boreal regions are expected to increase, although there may be significant spatial and temporal variability in the response of fire activity to climate change (Flannigan et al., 1998). Specifically, boreal climate change is expected to result in increased ignitions from lightning, increased fire season length and increased fire weather severity (Street, 1989; 
Flannigan and Van Wagner, 1991; Wotton and Flannigan, 1993; Price and Rind, 1994). Ignitions from lightning are expected to increase by 20 to $40 \%$ between 50 and 60 degrees north latitude due to the increased convective activity associated with a warmer atmosphere. Additionally, recent results for human-caused ignitions suggest increases of 18 and 50\% for 2050 and 2100, respectively, for Ontario (Wotton et al., 2003).

Several investigators have used General Circulation Models (GCM) to calculate Fire Weather Indices (FWI) (Nesterov, 1949; Harrington et al., 1983; Van Wagner, 1987; Flannigan and Harrington, 1988; Haines, 1988), which relate the potential for fire events to meteorological variables, in order to estimate potential fire weather under $2 \times \mathrm{CO}_{2}$ climate change scenarios. Wotton and Flannigan (1993) estimated the length of the fire season would be an average of 30 days (22\%) longer across Canada and up to 51 days longer in British Columbia. Using three GCMs, Flannigan and Van Wagner (1991) predicted a $46 \%$ increase in average seasonal severity, with a possible $40 \%$ increase in area burned. More recently, Flannigan et al. (2001) used Regional and GCM to determine FWI under $2 \times \mathrm{CO}_{2}$ and 6000 year BP (a warm period) scenarios. Results suggested that the FWI are expected to increase across most of Canada and decrease in much of eastern Canada, which correlates well with the historic temporal and spatial patterns of charcoal anomalies. Flannigan et al. (2005) estimated area burned in Canada may increase by $74-118 \%$ by the end of this century in $3 \mathrm{x}$ $\mathrm{CO}_{2}$ scenarios from the Canadian and Hadley GCMs. These estimates do not explicitly take into account any changes in vegetation, ignitions, fire season length or human activity (fire management and land use activities) that may influence area burned. Lastly, Bergeron (2004) found that estimates of future fire activity were less than the historical fire activity (pre- 
industrial) for many sites across the boreal forest, which adds support for projected estimates by demonstrating that the projected fire activity is within the limits of historical means.

Specifically, based on Canadian Climate Center climate change scenarios, fire weather severity is expected to increase both temporally and spatially in Alaska, Canada and Russia. Stocks and Lynham (1996) estimated that Canada and Russia will experience high to extreme fire danger conditions across large portions of these countries during the summer months. Fosberg et al. (1996) predicted an increase in high fire severity months and an increase in the geographic expanse of high fire severity in both Canada and Russia. Stocks et al. (2000) found a significant increase in extreme fire danger and an earlier start to the fire season in both Alaska and Canada under a $2 \mathrm{x} \mathrm{CO}_{2}$ scenario. Using four GCMs, Stocks et al. (1998) found strong geographic similarities in estimates of fire danger across Canada and Russia. Results indicated an earlier start to the fire season, an earlier start in high to extreme fire severity, a later end in the fire season, and a dramatic increase in the area under high to extreme fire danger. Notably, the area under extreme fire danger in Siberia during the summer months was projected to be three times the area affected in Canada.

Consequently, if the predictions are correct, under the currently warmer conditions in Alaska, Canada and Russia, we should expect to find increases in area burned, fire frequency, fire season length and/or fire severity. Fire severity is used here to define the severity of a fire in terms of the ecosystem. A low-severity fire might partially consume litter and understory ( $20 \%$ ), and in contrast, a high-severity fire might scorch forest crowns (resulting in tree death), consume $100 \%$ of the litter and understory, and burn into the soil organic layer. Boreal fire regimes are significant because they control the mosaic structure of the forests, which in turn controls the amount of carbon stored or released (Harden et al., 2000) and 
regional-scale albedo (relative reflectivity of the landscape), both of which directly feedback to the climate system (Chapin et al., 2000). For instance, Bonan et al. (1992; 1995) used model simulations to demonstrate that if the boreal forest was replaced by non-forest vegetation there would be significant cooling (albedo increase) and significant warming would result from boreal forest expansion (albedo decrease). If fire increases the proportion of early successional deciduous forest on the landscape, the resulting increase in albedo in both summer and winter and the reduction in Bowen ratio (i.e., proportional decline in sensible heat flux) should have a net cooling effect on regional climate (Chapin et al., 2000).

\subsubsection{Current wildfire situation in Siberia}

Even though the genera are equivalent and the species appear similar across the boreal zone, northern Eurasian species differentiated during the Quaternary glacial period and continued throughout interglacial periods (Tikhomirov, 1963). This resulted in the development of unique species assemblages and distinct cold resistant species in Siberia. This is important to fire regimes because specific species assemblages (cohorts) and forest structure characteristically coincide with specific fire regimes. A case in point is surface fires that burn every 20-50 years typically dominate larch [Larix (sp.)] and Pinus sylvestris forests, whereas crown fires that burn every 80-300 years characteristically dominate in darkconiferous forests. Dark-coniferous forests are productive, floristically rich, shade-tolerant, moisture demanding species assemblages [Pinus sibirica (Siberian cedar), Abies sibirica (Siberian fir) and Picea obovata (Siberian spruce)] that grow with a thick understory composed of a variety tree species, ferns and tall herbs, which, when they become dry, provide the ladder fuels necessary to sustain extreme crown fires. Because the average species composition in Russia is 31\% Larix (sp.) and 19\% P. Sylvestris (both light- 
demanding, light-needled forest), the fire regime in Russia has been historically dominated by surface fires (Alexeyev and Birdsey, 1998).

During normal fire years, about $22 \%$ of the area burned annually in Russia is by highseverity crown fires, and in extreme fire years, the area burned annually represents about $50 \%$ of the total area burned (Belov, 1976; Korovin, 1996). However, Soja et al. (2004a) found that high-severity crown fires dominated 4 of the 5 years from 1998 through 2002 [1998 (51\%); 1999 (24\%); 2000 (49\%); 2001 (47\%); 2002 (59\%)]. Extending that relationship, based on the relative percentage of large fire events, 2003 was an extreme fire year and 2004 was a normal fire year. Consequently 5 of the last 7 years or $72 \%$ of the years between 1998 and 2004 have been extreme fire years in Siberia. Although the increase in fire season severity is consistent with currently warmer conditions and with climate predictions, the high frequency of "extreme fire years" brings into question what is currently defined as a "normal" fire year.

Since 1995, the Sukachev Institute of Forestry in Krasnojarsk, Siberia has estimated area burned using satellite-derived data products (Soja et al., 2004b; Sukhinin et al., 2004). In Figure 4, these estimates are compared with other published estimates, and Figure 5 shows the distribution of fires across Siberia. Based on the Russian Federal Forest Service (RFFS) data, area burned in the warm decade of the 1990 s is $29 \%$ greater than the area burned during the 1980 s and $19 \%$ greater than the reported 47-year mean reported by Korovin (1996). The average difference between the satellite and RFFS data is $55 \%$, however caution is warranted when directly comparing the RFFS data to satellite-based data for several reasons. First, because Russian Siberia is remote and vast, about $40 \%$ of the Russian Forest Fund area was not protected, meaning that fire was and is not monitored, controlled or documented by the 
RFFS (Sofronov et al., 1998; Shvidenko and Nilsson, 2000). However, a substantial portion of this territory is located in the far north (tundra and sparse forests), where fires are less likely to burn. Secondly, historic fire records may have been under-reported before 1988 for economic and political reason (Shvidenko and Nilsson, 2000). Additionally, it is suspected that the satellite data overestimates some large fire events, and this analysis is currently being conducted at the University of Maryland. Even with these considerations, since 1998, both the satellite and RFFS data show an increase in area burned, which coincides with the current warmer and extended fire seasons, as well as the fire regime change predictions.

Place figure 4 and figure 5 about here.

\subsubsection{Current wildfire situation in North America}

In boreal North America, fire has been the dominant disturbance regime since the last Ice Age. Fire activity is strongly influenced by four factors - weather/climate, fuels, ignition agents and humans (Johnson, 1992; Swetnam, 1993; Kasischke and Stocks, 2000; Flannigan and Wotton, 2001). Observations of area burned for Canada are available from 1920 to present with corrections applied to account for regions with missing data (Figure 6) (Van Wagner, 1988). On average, there has been 1.59 million hectares ( $\mathrm{M}$ ha) burned annually since 1920, although there is great year-to-year variability with three years exceeding $6 \mathrm{M}$ ha, all of which burned since 1989. Approximately, 3\% of the fires are over 200 ha in size, but these are responsible for $97 \%$ of the area burned (Stocks et al., 2002). These large fires are typically stand-renewing crown fires (Figure 7). Lightning-ignited fires account for $80 \%$ of the area burned in Canada and $90 \%$ of the area burned in Alaska. In Alaska, human ignitions account for about $85 \%$ of the fires but only $10 \%$ of the area burned, because people light fire 
close to bases for fire suppression and at times in places where fire spread is less likely to occur (Kasischke et al., 2006; DeWilde and Chapin, in press).

Place figure 6 and figure 7 about here.

There has been an increasing trend in area burned over recent decades (Podur et al., 2002; Gillett et al., 2004; Kasischke et al., 2006) despite no trend in fire weather severity (Amiro et al., 2004; Girardin et al., 2004). The increasing trend of fire activity is occurring despite increased areas under fire suppression and more efficient fire suppression techniques. Gillett et al. (2004) suggested that fire activity in Canada was already increasing as a result of greenhouse warming. As shown in Figure 6, the Canadian fire inventory spans 84 years, and 5 of the 8 largest fire years transpired in the last 17 years $(1989-2005)$.

Alaska is similar to Russia and Canada in that there is a positive trend in area burned annually (Figures 4, 6, and 8), although the statistical relationships are not strong. The average area burned annually in Alaska is $0.4 \mathrm{M}$ ha, and the variability spans from 1,389 ha to $2.72 \mathrm{M}$ ha. Over the 56 years of record, seven of the eleven largest fire years have burned since 1988, which is also consistent with the increased number of large fire years in Canada and Russia. In Alaska, the largest fire year on record, in terms of area burned, is 2004 (6.8 times the 56-year mean) and the $3^{\text {rd }}$ largest is 2005 (4.7 times the mean). In other words, the frequency of extreme fire years has increased across the circumboreal region, and this is noteworthy. Additionally, if the area burned fire data for Alaska and Canada are combined, the positive linear relationship doubles. Combining these provides a realistic view of North American severe fire seasons, because they are largely under the control of continental-scale blocking ridges and large-scale weather patterns (Stocks and Street, 1982; Balzter et al., 2005). 
Place figure 8 about here.

Additionally, fire plays a major role in the carbon dynamics of the circumboreal region. In Canada, for the 1959-99 period, forest fires released an average of $27 \mathrm{Tg} \mathrm{C}$ per year, but in some years this exceeded $100 \mathrm{Tg}$ C (Amiro et al., 2001), and in Siberia, an average of $203 \mathrm{Tg} \mathrm{C}$ was released from forest fires in the years from 1998-2002 (Soja et al., 2004a). The positive feedbacks of carbon losses from global fire have the potential to be a major factor in our changing climate, whereby increased carbon emissions results in a warmer and drier climate, which will create conditions conducive to more fire. This in turn will increase carbon emissions from fires, which would continue to feed the warming. Although this scenario is possible, we believe that the boreal forests will have some limit to fire occurrence, since younger forests tend to be less susceptible to fire and have a cooling effect on climate at local to regional scales (Johnson, 1992; Baldocchi et al., 2000; Chapin et al., 2000).

Fire also has substantial social impacts in the short term through its risk to life and property and in the longer term through its effects on subsistence resources. Subsistence is a critical component of rural economies throughout the boreal zone (Chapin et al., 2004). Although the immediate effect of fire is to reduce availability of subsistence resources, over the longer term the early successional vegetation generated by fire is critical to the maintenance of important subsistence resources such as berries, moose, and furbearers. These resources are both an important component of the diet and critical to maintaining cultural ties to the land (Chapin et al., 2003).

\subsection{Increased insect disturbance in Alaska}


Although not fully appreciated before the 1990s, it is apparent that forest health in Alaska is being strongly affected by climate change. The connection between warm weather and insect outbreaks has been recognized (Berg et al., 2006), but the extreme impact of several years in a row of warm, dry summers on the Kenai Peninsula of Alaska on populations of forest insects was not expected. The multi-year outbreak of spruce beetle (Dendroctonus rufipennis (Kirby)), previously limited by cold, wet climate conditions, resulted in about 2.3 M acres (1 M ha) of tree mortality from 1992 to 2000 (National Assessment Synthesis Team, 2001) or 90\% of the region's spruce. The statewide spruce beetle infestation area mapped in 2004 increased from 2003 by more than $40 \%$ to 129063 acres (52 232 ha), but was below the peak outbreak level in 1996 (U.S. Department of Agriculture, 2005). The increase in the spruce beetle infestation area in 2004 was attributed to the record warm temperatures across Alaska in the summer of 2004, allowing outbreaks in interior and southwestern Alaska where residual stands of spruce were available despite activity during the peak outbreak years (U.S. Department of Agriculture, 2005). On the Kenai Peninsula, spruce beetle populations are now returning to endemic levels because suitable host trees, mature spruce (Picea spp.), have been decimated across the region. Although this and other incidences in recent years of broad-scale insect infestations have been documented across the state of Alaska (U.S. Department of Agriculture, 2005; Werner et al., 2005), a connection between climate and insect outbreaks has just recently been established through correlations between insect outbreaks, tree ring evidence and recorded air temperature (Berg et al., 2006). The outbreak appeared to be triggered in part when temperatures became warm enough for beetles to complete their life cycle in one rather than two years, suddenly shifting the balance between insects and tree defense in favor of the 
insect. However, very little has been reported in the literature, and no manipulative studies linking the events witnessed in the Kenai Peninsula to warmer climates have been documented. Despite this lack of complete documentation, experts agree that climate warming in Alaska has resulted in increased forest mortality from insects (National Assessment Synthesis Team, 2001). Researchers in non-boreal regions have also reported the effects of climate change on insect activity (Williams and Liebhold, 1995). Additionally, the National Assessment Synthesis Team (2001) stated that the projected warming trend is likely to increase the risk of insect disturbances in the future.

Multi-year outbreaks of spruce beetles, and indeed many forest insects, are not unusual (Berg et al., 2006). Many scientists believe these seemingly catastrophic events may be important over the long term in maintaining some forest ecosystems (Logan et al., 2003). However, few outbreaks have had the impact of the spruce beetle event on the Kenai, in both longevity and area. It is apparent that the increased mortality from this and similar outbreaks in the Alaskan Interior has begun to modify Alaskan forest ecosystems at broad spatial scales. In their 2004 forest health report, the USDA Forest Service states: “Many areas of the state have been rendered unsuitable for further, large-scale [spruce] beetle activity due to changes in stand structure and composition [from earlier beetle mortality]" (U.S. Department of Agriculture, 2005). The extensive change in infestation extent and severity documented in recent years has serious implications for vegetation composition and successional trajectory changes (Chapin et al., 2006b).

\subsection{Predicted vegetation shifts in montane southern Siberia.}

By the end of the $20^{\text {th }}$ century, scientifically sound evidence for global warming based on both direct weather observations and indirect physical and biological indicators had 
accumulated (IPCC, 2001). Mountainous regions are of special interest in climate-change studies because they are extremely vulnerable lands where ongoing climate change could quickly disturb the delicate balance between the natural ecological components within these systems (biotic and abiotic). Guisan et al. (1995) stressed that monitoring treeline shifts was an excellent tool for detecting the earliest signs of climate change impacts, and mountainous regions are located where initial disturbance is expected to be observed. Due to the combination of micro-climates, unique soils and complex topography, numerous diverse habitats have evolved. Habitats that differ in terms of water and energy resources may be located at short distances (hundred meters), in contrast to the plains, where contrasting habitats are located at distances of hundreds of kilometers. The complex environmental patterns that occur at short distances across mountainous landscapes create the opportunity for species to successfully escape unfavorable habitats and approach suitable habitats (refuges) by simple migration. The speed of natural migration corresponds to the distances between these habitats. Therefore, many refuges are found across mountains, similar in nature to the Tertiary flora refuges that are currently found across the Altai-Sayan Mountains (Polozhiy and Krapivkina, 1985). Additionally, in comparison to the plains, mounatins are known to have higher biodiversity and a greater number of endemic species (Guisan et al., 1995). The point here is that becaue these regions are expeced to be a primary region of warming and diversity exists within small distances, these are regions where the initial signs of change will be found.

The IPCC (2001) suggested that temperature increases, under current climate change scenarios, would result in an upward shift of vegetation zones in mountainous regions. Plant species are expected to be redistributed and some are expected to become extinct. Vlasenko 
(2000) postulated that the climate in the Altai-Sayan Mountains would be similar to that of the mid-Holocene, where vegetation elevation belts shifted 200-400 $\mathrm{m}$ upwards. Tchebakova and her colleagues used models to investigate potential climate change impacts on several montane biomes in southern Siberia, which include the Altai (Parfenova and Tchebakova, 2000); the Sayans (Tchebakova et al., 2001); and Transbaikalia (Parfenova and Tchebakova, 2000) (Figure 9). These mountains are located within the $50-56^{\circ} \mathrm{N}$ latitude band and are at the limit of the southern boreal zone. Conservative climate change scenarios, taken from six GCMs, were used to model vegetation cover in 2100 (summer temperature increase $2^{\circ} \mathrm{C}$, annual precipitation increase 20\%) (IPCC, 1996). Under this climate change scenario, significant vegetation shifts were predicted in every montane region. The mountain tundra and highland sparse forest were predicted to remain as only remnants, replaced by montane taiga. In addition, the models estimated that the upper treeline would shift upland in elevation by about $400 \mathrm{~m}$, and it was predicted that the transitional lowland forest-steppe biome would double. The model estimated that the lower treeline was expected to shift upwards by about $250 \mathrm{~m}$. The lowland dark-needled taiga dominated by Abies sibirica and Pinus sibirica [in Russian geobotanic literature "chern" (black) taiga, a specific type of darkconiferous forest] was predicted to expand across the Altai-Sayan mountains in a warmer climate (Parfenova and Tchebakova, 2000). The unique "chern" taiga is a successor of broadleaf forests, which were distributed throughout much of Siberia during the midHolocene warm period, and this relic vegetation cohort has remained since the Tertiary period. Chern taiga is a productive and floristically rich forest type with numerous ferns, and it thrives in the warm and moist habitat of the Altai-Sayan foothills. Overall, model results 
indicated both upslope shifts and structural changes in vegetation composition, as the climate changed.

Place figure 9 about here.

\subsubsection{Evidence of vegetation change in montane southern Siberia.}

Warming in southern Siberia during the $20^{\text {th }}$ century is evident and has manifested itself in the current shift in montane vegetation. In fact, the last decade (1990-99) was the warmest in the $20^{\text {th }}$ century, as shown in Table 1 . In some regions of the Sayan Mountains, winter temperatures have already exceeded those predicted by a Hadley Centre scenario for 2090, as shown in Figure 10. This example suggests that some of the warming, hence change, may be more rapid than predicted. The $21^{\text {st }}$ century is predicted to be $2-10^{\circ} \mathrm{C}$ warmer than the $20^{\text {th }}$ century, while associated warming rates, as suggested from paleo-climatic reconstructions, are expected to be the largest in 10000 years (IPCC, 2001).

Place figure 10 about here.

By the end of $20^{\text {th }}$ century, climate change in montane southern Siberia was evident in both the summer and winter (Table 1 and Figures 1 and 10). Average summer temperatures [July or average June, July and August (J-J-A)] increased between 0-0.5 ${ }^{\circ} \mathrm{C}$ from 1960-1999, with a significant increase of $1-2^{\circ} \mathrm{C}$ in the last decade. Average winter temperatures [January or an average for December, January and February (D-J-F)] increased tremendously from 1$4.5^{\circ} \mathrm{C}$ for 40 years, with an increase greater than $2-3^{\circ} \mathrm{C}$ in the last decade. January and July temperatures explain $96 \%$ of the variance in the growing season duration (Figure 11 and Table 1). This is important because increases in winter and summer temperatures of only $1^{\circ} \mathrm{C}$ will extend the growing season by 9 days. This is particularly significant in interior, dry continental lands, where the temperatures are expected to increase the growing season by 2 to 
3 weeks. In regions that are moderated by the Atlantic Ocean influence (i.e.Urals), the growing season is expected to increase by only 2 to 3 days. Vegetation, insects and fire regimes are all strongly influenced by warmer temperatures and the growing season length.

Place figure 11 about here.

Precipitation patterns are more complicated. In some regions, precipitation has remained the same (Transbaikalia). Precipitation on windward slopes in both the Urals and the Altai has increased up to $130-260 \mathrm{~mm}$ for 40 years due to the stronger Atlantic influence. On the other hand, a drastic decrease in precipitation of $230 \mathrm{~mm}$ over 40 years has been noted on leeward slopes of the Sayans in the interior of Siberia (Table 1).

Upper treeline shifts have been registered (description from west to east) in the southern Urals (Shiyatov et al., 2001), in the Altai (Ovchinnikov and Vaganov, 1999; Timoshok et al., 2003), in the Sayans (Vlasenko, 2000; Istomov, 2005) and in the Kuznetsky Alatau (Moiseev, 2002). Photos taken of the southern Urals in the 1950s, 1970s, and at the end of the $20^{\text {th }}$ century were compared to measure potential vegetation shifts. In the middle of the last century, 10-20\% of the top of the Far Taganai mount was covered with spruce groves of 1-2 m high; in the 1970s, 30-50\% was covered by sparse spruce forests (2-4 m high); and currently, spruce trees 5-7 $\mathrm{m}$ in height cover 50-80\% of the mount. The treeline of stocked forests moved 20-40 m upwards and decreased the adjacent tundra by a factor of two. Also in the mid-20th century, the overall tundra distribution was 4-5 times greater than today. At this rate of forest advance, the mountain tundra in the Far Taganai mount will rapidly disappear.

In the Altai Mountains, which are famous for their glaciers, the area occupied by glaciers decreased notably from 1958-1998; the aerial extent decreased 7\%, while the ice 
volume of the glaciers decreased $10 \%$. During the $20^{\text {th }}$ century, the rate of glacial retreat varied from 12-17.5 m per year and up to 25-27 m year (Mikhailov and Ostanin, 2001; Narozhnyi et al., 2002). Moraines, left by glaciers, are currently being colonized by highland vegetation. During the Little Ice Age, the Big and Small Aktru glaciers advanced down-slope and disturbed the forest zone several times during the $16^{\text {th }}$ and $17^{\text {th }}$ centuries, and from 19521998, these glaciers retreated 250 to $450 \mathrm{~m}$. Young larch (Larix sibirica) and Siberian pine (P. sibirica) forests that survived in relic forest refuges are currently moving upslope and are colonizing the moraines (Timoshok et al., 2003). Additionally, numerous tree rings were measured from the upper tree line across the vast montane Altai-Sayan territory, and Ovchinnikov and Vaganov (1999) suggested that the extensive tree ring growth was directly related to the warmer $20^{\text {th }}$ century climate.

In the Western Sayan Mountains, Vlasenko (2000) completed a forest inventory in the Sayan-Shush Reserve and found that $6 \%$ of the open forests bordering the treeline were young $P$. sibirica, aged between $40-80$ years. She concluded that recent climate warming caused this forest invasion into the tundra. This relatively abrupt upslope shift in the $P$. sibirica treeline was confirmed by satellite images, which showed a treeline shift of $120 \mathrm{~m}$ over the last 63 years, with the largest rate of movement beginning in the early 1970s (Istomov, 2005). One mechanism for the successful $P$. sibirica regeneration may be that the percentage of full seeds in $P$. sibirica cones in the open highland forests was recently found to have significantly increased (Ovchinikova, personal communication).

On the lower treeline, lowland "chern" forests (floristically rich with ferns and tall herbs) were predicted to shift upslope and to partially replace montane dark taiga in a warmer climate (Parfenova and Tchebakova, 2000). In contrast to this prediction, Ovchinnikova and 
Ermolenko (2004) concluded that the significantly decreased $P$. sibirica seed production in the "chern" forests in the West Sayan from 1990-1999 was related to climate change. One possible hypothesis is a warmer climate increases moth populations [Dioryctria abietella (Schft.)], which damage P. sibirica seeds (Ermolenko, personal communication). In the Bargizin Reserve of Transbaikalia, reduction of $P$. sibirica seed production was also noted in the 1990s and related to climate warming (Ananin et al., 2002). Along with poor seed production, warmer spring and summer temperatures resulted in other phenological changes. For instance, the longer frost-free period resulted in an earlier birch and larch bud burst. Also, because precipitation remained the same under elevated spring and summer temperatures (increased evapotranspiration), the fire danger situation increased, with an associated increase in forest fire occurrence. Increased incidence of anthropogenic fire has contributed to a southerly movement of the treeline in Russia (Vlassova, 2002). These examples highlight the complexity of interactions between the biotic and abiotic terrestrial environment and climate.

Additionally, in the lowlands of the eastern Sayan Mountains, within the Krasnojarsk region, climate warming has resulted in biological shifts in the seed production capability of both $L$. sibirica and $P$. sylvestris. Specifically, warm falls, characterized by an absence of early frosts and a longer growing period, have damaged microsporocytes (mother cells). An earlier fall meiosis has caused the species to remain in prophase-I over the winter, damaging embryonic development, leading to poor pollen quality and low pollen quantity. The result is poor cone and seed yield in L. sibirica and $P$. sylvestris (Noskova et al., 2004), ultimately affecting forest composition and structure. 
The hardiest tree species in the world are found in the forests of East Siberia, where the climate is extremely cold and extremely dry (can reach $-70^{\circ} \mathrm{C}$, Verhoyansk $155 \mathrm{~mm}$ mean annual precipitation) (Lydolph, 1985). L. gmelinii and L. cajanderi are the only tree species capable of growing on the shallow permafrost and cold soils of this extreme environment. Because the environment is dry, slow melting permafrost provides the moisture necessary to support forest growth in the summer in this geographically expansive region (> $2 \mathrm{M} \mathrm{km}^{2}$ ) (Walter, 1979). In these dry conditions, under current climate change scenarios, steppe or semidesert regions were predicted to succeed the current larch forests (Shumilova, 1962). Additionally, permafrost currently limits the distribution of dark-needled species ( $P$. sibirica, A. sibirica and Picea obovata) and light-needled L. sibirica to about $62^{\circ} \mathrm{N}$ latitude, $95^{\circ} \mathrm{E}$ longitude (Pozdnyakov, 1993). A few small P. sibirica and Abies groves (40-50 years) were recently found in the Putorana Plateau (Ivanov, personal communication), a distance of 500 $\mathrm{km}$ from their typical northern treeline. Pozdnykov recognized these refuges in the early sixties.

Retreating permafrost has permitted the continued northward migration of darkneedled species. Currently, permafrost degradation in the mountains around Lake Hovsgol, Mongolia, has been extreme (Sharkhuu, 2003). We hypothesize that in the near future, $P$. sibirica undergrowth will appear in larch forests currently found around the lake. In addition, Moiseev (2002) recently postulated the stand age structure and intensive larch regeneration at the Kuznetsky Alatau treeline over the last 30 years was directly related to climate warming.

The upper and lower treelines of the mountainous regions across southern Siberia have been altered in response to the currently warmer conditions, as predicted. The modification of this landscape manifests itself by: (1) species direct progression northward or 
upslope of previous climatological limits; (2) the modification of species ability to reproduce;

(3) altered soil properties (permafrost) and ecological conditions; and/or (4) increased fire disturbance regimes, which modifies the environment and alters species composition. These large-scale modifications of the landscape feedback to the regional energy and water balances, thus continuing to influence regional- to global-scale weather and climate.

\subsection{Predicted vegetation change in Alaska}

Evidence has been mounting that shows plant growth at Northern latitudes has increased (Myneni et al., 1997; Sturm et al., 2001; Tape, 2004). Studies have also shown that interior Alaska has experienced warmer growing season temperatures since 1950 (Barber et al., 2000; Keyser et al., 2000; Juday et al., 2003; Hinzman et al., in press). Using historic Advanced Very High Resolution Radiometer (AVHRR) satellite imagery from 1981 to 1991, Myneni et al.(1997) found vegetation indices had increased over the decade of record north of $45^{\circ} \mathrm{N}$ latitude, which suggested plant growth had increased. Sturm et al. (2001) showed similar evidence from historic photographs of areas in Alaska. However, since 1990, the satellite-based Normalized Difference Vegetation Index (NDVI) in boreal Alaska has declined, suggesting drought-induced declines in growth, whereas NDVI in the cooler wetter tundra has continued to increase (Angert et al., 2005; Goetz et al., 2005). Furthermore, recent Alaskan studies demonstrated that a complex relationship exists between climate and tree growth (Barber et al., 2000; Lloyd and Fastie, 2002; Barber et al., 2004; Wilmking et al., 2004), and in particular, population-wide white spruce [Picea glauca (Moench (Voss))] response to warmer temperatures at the treeline is not straightforward and is not unconditionally increasing (Wilmking et al., 2004). 
In the late-1960s, in several forestry schools across the United States, a forest modeling approach developed based on simulating a forest by computing the birth (or planting), growth and death (thinning or harvest) of plantation forests. This emphasis on tracking individual trees was soon taken up by forest ecologists interested in the simulation of forest structural and compositional changes in forest succession and in response to environmental gradients (Shugart, 1998). One of the features of these early individual-based forest simulators (Huston et al., 1988) was geometrically elaborate computation of the effect of each tree on the others through shading or the use of nutrient and/or water resources. One simplification of the rather laborious calculations was to assume the competitive interactions were primarily occurring on a plot of land that was roughly the size of a very large canopy tree. This is the space scale of a gap in a forest canopy associated with a large tree's death. Hence, this class of models was termed "gap models" (Shugart and West, 1980). More powerful modern computers have lifted the computational limitations that mandated the gap model's competition-simplification. Nowadays, "gap model" refers to individual-based models of natural multi-species forests with natural regeneration.

Gap models provide a quantitative tool for evaluating the effects of climate change on forests (and other) ecosystems. The entry of these models into climate change evaluation was initially in reconstructing the expected forests under past climatic conditions (Solomon et al., 1980; Solomon and Webb III, 1985). These paleoecological applications lead naturally to an interest in applying the models to predict the expected forests under future, novel climate conditions — such as those expected from "greenhouse warming" associated with elevated concentrations of $\mathrm{CO}_{2}$ and other radiatively active gasses in the atmosphere. 
In the early 1990s, Bonan et al. (1989b) and Smith et al. (1995) used a boreal forest gap model to assess climate change effects to the forest in the vicinity of Fairbanks, Alaska. They investigated the responses to several climate change predictions from general circulation models for several hundred years on 100 simulated plots and for conditions associated with north-facing and south-facing slopes. The cold forests of black spruce growing on north-facing slopes were largely unaffected by climatic warming, but the warmer, white spruce forests of the south-facing slopes were strongly affected by the predicted changes in climate (Figure 12). Conditions on the south-facing slopes were outside the ecological conditions under which the common tree species near Fairbanks are known to be able to persist. For white spruce, the limiting condition appeared to be moisture stress brought on by the elevation in evapotranspiration associated with warmer temperatures. There were several important implications to this model based study. First, the response to a climatic warming for the region was heterogeneous particularly with respect to landscape conditions. Effects were negative on south facing slopes and positive (or neutral) on tree performance on north-facing slopes. Presumably, this latter result should also hold in Black Spruce-dominated cold and poorly drained sites. Second, the increased productivity one might expect from a warming in this location in the middle- to upper-range of the boreal forest zone was moderated by moisture stress. Third, none of these effects are in the repertoire of larger spatial scale homogeneous models used for many of the international assessments of the feedbacks among climate change, vegetation performance and the global carbon budget.

Place figure 12 about here. 
When landscape processes of fire, succession, and migration are incorporated into boreal simulations, the changes predicted by gap models for specific sites are magnified in extent. Warming will likely increase the proportion of early successional forests on the landscape and could increase the areal extent of grasslands to create an aspen parkland (Starfield and Chapin, 1996; Rupp et al., 2000).

\subsubsection{Decreased white spruce growth in Alaska}

Over a decade after model-based studies, several detailed investigations have demonstrated that the relationship between vegetation and climate is indeed complex, as suggested by the models, and that increased treeline productivity due to warmer temperatures at Northern latitudes may not be as straightforward as had been thought. For instance, Lloyd and Fastie (2002) investigated the response of trees growing at the cold margins of the boreal forest to climate variation in the 20th century. By comparing tree growth (measured tree ring-widths) to historic climate data they found regional variability in response to climate variation. After 1950, warmer temperatures were associated with decreased tree growth in all but the wettest regions. The study also showed substantial variability in response to climate variation according to distance to treeline. Specifically, tree growth at sites below the forest margin was inhibited more often than at sites at the forest margin. Consequently, the Lloyd and Fastie investigation showed that growth declines were most common in the warmer and drier sites, and thus supports the hypothesis that drought-stress may accompany increased warming in the boreal forest.

In another investigation, Wilmking et al. (2004) collected tree ring samples from 1558 white spruce at treeline sites in Alaska. Tree core samples were compared with mean monthly temperature and total monthly precipitation records from the early 1900s to the 
present. Results showed no correlation to climate for $25 \%$ of the samples. For $40 \%$ of the white spruce sampled, a statistically significant relationship showed warmer July temperatures resulted in decreased growth, whereas warm spring conditions enhanced growth of $36 \%$ of trees. Opposing growth responses were present in all sites, but with varying proportion of impact on net growth. Wilmking and colleagues highlight tree growth as having temperature thresholds where, in the case of warm July temperatures, little change in radial growth was apparent at temperatures $<\sim 16^{\circ} \mathrm{C}$, whereas a strong significant negative relationship between July temperature and growth was found for temperatures $>\sim 16^{\circ} \mathrm{C}$. Similarly, the spring temperature effects were apparent above certain threshold temperatures, but only after 1950 .

Additionally, Barber et al. (2000) documented a negative growth response in Alaskan white spruce to drought. In tree-ring studies near Fairbanks, Barber et al. $(2000 ; 2004)$ used a combination of analysis of late wood rings and the $\mathrm{d}^{13} \mathrm{C}$ isotope ratios to investigate the effects of historical runs of warmer-than-usual decades on white spruce. Barber and her colleagues found evidence of the same moisture-stress-mediated effect predicted by the earlier gap model study.

Notably each of these investigations came to the same conclusion (seemingly independently) of the model-based study over a decade before. Results from the Lloyd and Fastie and Wilmking et al. investigations suggested that inverse responses to temperature were widespread, affecting even the coldest parts of the boreal forest. The authors of these two studies point out that the observed responses to temperature may be induced by indirect effects, such as increased shrubbiness, warming of the permafrost, or changes in the nutrient regime. Positively responding trees from springtime climate changes may be a result of the 
documented lengthening of the growing season in the north (Myneni et al., 1997).

Differences detected between study sites in central Alaska versus sites in northern Alaska, may reflect the onset of snowmelt at the sites (Wilmking et al., 2004). The studies reveal that some of the model-based predictions of increased carbon uptake due to a warming northern climate may be imprecise, as impacts of warming on permafrost conditions can modify soil water availability and can result in increases in drought stress during summer months.

Having identified a need to account for the landscape-scale environmental responses of different boreal zone tree species, work is now underway to produce a regional scale version of the same type of gap model used in the Fairbanks study. An initial East Eurasian prototype has been developed (Yan and Shugart, in press) and climate-change-related inspections are being developed.

\subsection{Conclusions}

Scientific evidence of the transformation of landscapes due to changes in climate is mounting throughout the circumboreal zone in Alaska, Canada and Russia. In this investigation, we reviewed previous predictions of climate-induced landscape-scale change in an effort to determine whether the currently warmer conditions have resulted in the predicted effects. We found that the predicted keystone indicators of initial change demonstrate that alterations in ecosystems are currently underway. Given the increases in temperature in boreal regions over the last decades, these modifications of the landscape are in agreement with modeled predictions. In some instances the warming and/or the effect of warming is more rapid than predicted, suggesting potential non-linear rapid change, as opposed to a slow linear progression of change. 
Specific ecological indicators of "predicted" climate-related change found in this investigation include: (1) the progression in elevation of the lower and upper treelines in the southern mountains across Russia; (2) a decline in the growth and health of white spruce trees in Alaska; (3) an increase in landscape- and regional-scale infestation in Alaska; (4) an indication of increased area burned by fire in Alaska, Canada and Russia; and (5) an increase in the number of large (or severe) fire seasons in Alaska, Canada and Siberia.

Not only is the boreal region significant as an area where the initial signs of climateinduced change are expected, but this region is also notable because it has the size and ecosystem contrasts necessary to influence climate through feedbacks to the climate system. Current species composition may be altered directly through changes in climate or indirectly through wildfire and infestation disturbance (Weber and Flannigan, 1997; Dale et al., 2001). Alteration of these ecosystems will affect short- and long-term carbon storage within the ecosystems, which is significant considering that the boreal region stores the largest pool of terrestrial carbon. Additionally, changes in the mosaic pattern of the landscape alter landscape- and regional-scale albedo, which is a direct feedback to the solar radiation balance and climate.

Having identified a host of direct and indirect alterations of ecosystems across the circumboreal, which have the potential to feedback to the climate system, we look forward to the inclusion of an interactive biosphere in global models that anticipate future climate change. 


\section{Acknowledgements}

We would like to express thanks to two anonymous reviewers who offered helpful suggestions, which led to an improved manuscript. Additionally, this research would not have been possible without funding through a Research Associateship provided by the National Aeronautics and Space Administration (NASA) Land Cover Land Use Change (LCLUC) program and the National Research Council (NRC), and we owe these organizations a debt of gratitude. Also, we gratefully acknowledge the Russian Academy of

Sciences, the Russian Foundation for Basic Sciences (06-05-65127) and NASA Langley Research Center for providing support for this research. 
References

ACIA, 2004. Impacts of a Warming Arctic. Cambridge University Press, Cambridge.

Alexeyev, V.A. and Birdsey, R.A., 1998. Carbon storage in forests and peatlands of Russia. Gen. Tech. Rep. NE 244, U.S.D.A. Forest Service Northeastern Research Station, Radnor.

Amiro, B.D., Logan, K.A., Wotton, B.M., Flannigan, M.D., Todd, J.B., Stocks, B.J. and Mattell, D.L., 2004. Fire weather index system components of large fires in the Canadian boreal forest. International Journal of Wildland Fire. 13, 391-400.

Amiro, B.D., Todd, J.B., Wotton, B.M., Logan, K.A., Flannigan, M.D., Stocks, B.J., Mason, J.A., Martell, D.L. and Hirsch, K.G., 2001. Direct carbon emissions from Canadian forest fires, 1959-1999. Canadian Journal of Forest Research. 31, 512-525.

Ananin, A.A., Ananina, T.L., Darigapova, E.A., Puzachenko, A.Y. and Fadeev, A.S., 2002. Climate change influence on biota of the Barguzin Reserve. In: A. Kokorin, A. Kojarinov and A. Minin (Editors), Climate change impacts on ecosystems. Protected natural territories of Russia: Analyses of long-term observations, Moscow, pp. II 1-7.

Angert, A., Biraud, S., Bonfils, C., Henning, C.C., Buermann, W., Pinzon, J., Tucker, C.J. and Fung, I., 2005. Drier summers cancel out the $\mathrm{CO}_{2}$ uptake enhancement induced by warmer springs. Proceedings of the National Academy of Sciences of the United States of America. 102(31), 10823-10827.

Anisimov, O.A. and Belolutskaya, M.A., 2002. Evaluation of the effect of climate change and permafrost degradation on infrastructure in the northern regions of Russia. Russian Meteorology and Hydrology(6), 9-14.

Antonovski, M.Y., Ter-Mikaelian, M.T. and Furyaev, V.V., 1992. A spatial model of longtem forest fire dynamics and its applications to forests in western Siberia. In: H.H. Shugart, R. Leemans and G.B. Bonan (Editors), A Systems Analysis of the Global Boreal Forest. Cambridge University Press, New York, pp. 373-403.

Apps, M.J., Kurz, W.A., Luxmoore, R.J., Nilsson, L.O., Sedjo, R.A., Schmidt, R., Simpson, L.G. and Vinson, T.S., 1993. Boreal forests and tundra. Water Air and Soil Pollution. 70(1-4), 39-53.

Baldocchi, D., Kelliher, F.M., Black, T.A. and Jarvis, P.G., 2000. Climate and vegetation controls on boreal zone energy exchange. Global Change Biology 6 (Suppl. 1), 69-83.

Balling, R.C., Michaels, P.J. and Knappenberger, P.C., 1998. Analysis of winter and summer warming rates in gridded temperature time series. Climate Research. 9, 175-181.

Balzter, H., Gerard, F.F., George, C.T., Rowland, C.S., Jupp, T.E., McCallum, I., Shvidenko, A., Nilsson, S., Sukhinin, A., Onuchin, A. and Schmullius, C., 2005. Impact of the Arctic Oscillation pattern on interannual forest fire variability in Central Siberia. Geophysical Research Letters. 32(14), doi:10.1029/2005GL022526.

Baranchikov, Y.N., Perevoznikova, V.D., Kondakov, Y.P. and Kirichenko, N.I., 2002. Zoogenic contribution to carbon emissions from Siberian moth outbreaks. In: F.I. Pleshikov (Editor), Forest Ecosystems of the Yenisei Meridian. Publishing House of Siberian branch of Russian Academy of sciences, Novosibirsk, pp. 117-123.

Barber, V.A., Juday, G.P. and Finney, B.P., 2000. Reduced growth of Alaskan white spruce in the twentieth century from temperature-induced drought stress. Nature. 405, 668-673. 
Barber, V.A., Juday, G.P., Finney, B.P. and Wilmking, M., 2004. Reconstruction of Summer Temperatures in Interior Alaska from Tree-Ring Proxies: Evidence for Changing Synoptic Climate Regimes. Climatic Change. 63(1-2), 30.

Baumgartner, A., 1979. Climatic variability and forestry, World Meteorological Organization. Proceedings of the World Climate Conference, Geneva, pp. 581-607.

Belov, S.V., 1976. Forest Pyrology. Leningrad Forestry Academy of the USSR, St. Petersburg, Russia, pp. (in Russian).

Berg, E.E., Henry, J.D., Fastie, C.L., De Volder, A.D. and Matsuoka, S.M., 2006. Spruce beetle outbreaks on the Kenai Peninsula, Alaska, and Kluane National Park and Reserve, Yukon Territory: Relationship to summer temperatures and regional differences in disturbance regimes. Forest Ecology and Management. 227(3), 219-232.

Bergeron, Y., 2004. Is regulated even-aged management the right strategy for the Canadian boreal forest? The Forestry Chronicle. 80(4), 458-462.

Bonan, G.B., 1988. Environmental Processes and Vegetation Patterns in Boreal Forests. Dissertation Thesis, University of Virginia, Charlottesville, 297.

Bonan, G.B., 1989a. A computer-model of the solar-radiation, soil-moisture, and soil thermal regimes in boreal forests. Ecological Modelling. 45(4), 275-306.

Bonan, G.B., 1989b. Environmental factors and ecological processes controlling vegetation patterns in boreal forests. Landscape Ecology. 3(2), 111-130.

Bonan, G.B., Chapin III, F.S. and Thompson, S.L., 1995. Boreal forest and tundra ecosystems as components of the climate system. Climatic Change. 29(2), 145-167.

Bonan, G.B., Pollard, D. and Thompson, S.L., 1992. Effects of boreal forest vegetation on global climate. Nature. 359, 716-718.

Bonan, G.B. and Shugart, H.H., 1989. Environmental-factors and ecological processes in boreal forests. Annual Review of Ecology and Systematics. 20, 1-28.

Budyko, M.I., Izrael, Y.A., MacCaren, M.C. and Hecht, A.D., 1991. Forthcoming climate change. Hydrometeorizdat. Leningrad (in Russian).

Cahoon, D.R., Jr., Stocks, B.J., Levine, J.S., Cofer III, W.R. and Barber, J.A., 1996. Monitoring the 1992 forest fires in the boreal ecosystem using NOAA AVHRR satellite imagery. In: J.S. Levine (Editor), Biomass Burning and Global Change. MIT Press, Cambridge, Mass., pp. 795-801.

Cahoon, D.R., Jr., Stocks, B.J., Levine, J.S., Cofer III, W.R. and Pierson, J.M., 1994. Satellite analysis of the severe 1987 forest fires in northern China and southeastern Siberia. Journal of Geophysical Research. 99(D9), 18627-18638.

Camill, P., 2005. Permafrost thaw accelerates in boreal peatlands during late-20th century climate warming. Climatic Change. 68(1-2), 135-152.

Candau, J.-N. and Fleming, R.A., 2005. Landscape-scale spatial distribution of spruce budworm defoliation in relation to bioclimatic conditions. Canadian Journal of Forest Research. 35, 2218-2232.

Chapin, F.S., III, McGuire, A.D., Randerson, J., Pielke, R., Sr., Baldocchi, D., Hobbie, S.E., Roulet, N., Eugster, W., Kasischke, E., Rastetter, E.B., Zimov, S.A. and Running, S.W., 2000. Arctic and boreal ecosystems of western North America as components of the climate system. Global Change Biology 6 (Suppl. 1), 1-13.

Chapin, F.S., III, Oswood, M., Cleve, K.V., Viereck, L.A. and Verbyla, D., 2006a. Alaska's Changing Boreal Forest. Oxford University Press, Oxford, pp. 354. 
Chapin, F.S., III, Peterson, G., Berkes, F., Callaghan, T.V., Angelstam, P., Apps, M., Beier, C., Bergeron, Y., Crépin, A.S., Danell, K., Elmqvist, T., Folke, C., Forbes, B., Fresco, N., Juday, G., Niemela, J., Shvidenko, A. and Whiteman, G., 2004. Resilience and vulnerability of northern regions to social and environmental change. Ambio. 33, 344-349.

Chapin, F.S., III, Rupp, T.S., Starfield, A.M., DeWilde, L., Zavaleta, E.S., Fresco, N. and McGuire, A.D., 2003. Planning for resilience: Modeling change in human-fire interactions in the Alaskan boreal forest. Frontiers in Ecology and the Environment. 1(255-261).

Chapin, F.S., III, Yarie, J., Cleve, K.V. and Viereck, L.A., 2006b. The conceptual basis of LTER studies in the Alaskan boreal forest. In: F.S. Chapin, III, M. Oswood, K.V. Cleve, L. A. Viereck and D.L. Verbyla (Editors), Alaska's Changing Boreal Forest. Oxford University Press, Oxford, Oxford, pp. 3-11.

Chudnikov, P.I., 1931. Impact of Fire on Regeneration of Urals Forests. Selkhozgiz (Agricultural State Publishing House), Moscow, pp. (in Russian).

Clark, J.S., 1988. Effect of climate change on fire regimes in northwestern Minnesota. Nature. 334, 233-235.

Conard, S.G., Sukhinin, A.I., Stocks, B.J., Cahoon, D.R., Jr., Davidenko, E.P. and Ivanova, G.A., 2002. Determining effects of area burned and fire severity on carbon cycling and emissions in Siberia. Climatic Change. 55(1-2), 197-211.

Dale, V.H., Joyce, L.A., McNulty, S., Neilson, R.P., Ayres, M.P., Flannigan, M.D., Hanson, P.J., Irland, L.C., Lugo, A.E., Peterson, C.J., Simberloff, D., Swanson, F.J., Stocks, B.J. and Wotton, B.M., 2001. Climate change and forest disturbances. Bioscience. 51(9), 723 734.

DeWilde, L. and Chapin, F.S., III, in press. Human impacts on the fire regime of Interior Alaska: Interactions among fuels, ignition sources and fire suppression. Ecosystems.

Flannigan, M.D., Bergeron, Y., Engelmark, O. and Wotton, B.M., 1998. Future wildfire in circumboreal forests in relation to global warming. J. Veg. Sci. 9, 468-476.

Flannigan, M.D., Cambell, I., Wotton, B.M., Carcaillet, C., Richard, P. and Bergeron, Y., 2001. Future fire in Canada's boreal forest: Paleoecology results and General Circulation Model-Regional Climate Model simulations. Canadian Journal of Forest Research. 31, 854-864.

Flannigan, M.D. and Harrington, J.B., 1988. A study of the relation of meteorological variables to monthly provincial area burned by wildfire in Canada. Journal of Applied Meteorology. 27, 441-452.

Flannigan, M.D., Logan, K.A., Amiro, B.D., Skinner, W.R. and Stocks, B.J., 2005. Future area burned in Canada. Climatic Change. 72(1-2), 1-16.

Flannigan, M.D. and Van Wagner, C.E., 1991. Climate change and wildfire in Canada. Canadian Journal of Forest Research. 21, 66-72.

Flannigan, M.D. and Wotton, B.M., 2001. Climate weather and area burned. In: E.A. Johnson and K. Miyanishi (Editors), Forest Fires: Behavior and Ecological Effects. Academic Press, pp. 335-357.

Fleming, R.A., 2000. Climate Change and insect disturbance regimes in Canada's boreal forests. World Resource Review. 12(3), 520-554.

Fleming, R.A., Candau, J.-N. and McAlpine, R.S., 2002. Landscape-scale analysis of interactions between insect defoliation and forest fire in central Canada. Climatic Change. 55(1-2), 251-272. 
Folland, C.K., Karl, T.R., Christy, J.R., Clarke, R.A., Gruza, G.V., Jouzel, J., Mann, M.E., Oerlemands, J., Salinger, M.J. and Wang, S.W., 2001. Observed climate variability and change. In: J.T. Houghton, Y. Ding, D.J. Griggs, M. Noguer, P.J. van der Linden, X. Dai, K. Maskell and C.A. Johnson (Editors), Climate Change 2001: The Scientific Basis. Contribution of Working Group I to the Third Assessment Report of the Intergovernmental Panel on Climate Change. Cambridge University Press, New York, USA, pp. 99-181.

Fosberg, M.A., Stocks, B.J. and Lynham, T.J., 1996. Risk analysis in strategic planning: Fire and climate change in the boreal forest. In: J.G. Goldammer and V.V. Furyaev (Editors), Fire in Ecosystems of Boreal Eurasia. Kluwer Academic Publishers, Boston, Mass., pp. 481-494.

French, N.N.F., 2002. The Impact of Fire Disturbance on Carbon and Energy Exchange in the Alaskan Boreal Region: A Geospatial Data Analysis. Ph.D. dissertation Thesis, University of Michigan, Ann Arbor, 105.

Furyaev, V.V. and Kireev, D.M., 1979. A landscape approach in the study of postfire forest dynamics, Nauka, Novosibirsk, pp. (in Russian).

Gillett, N.P., Weaver, A.J., Zwiers, F.W. and Flannigan, M.D., 2004. Detecting the effect of climate change on Canadian forest fires. Geophysical Research Letters. 31(18), DOI 10 1029/2004GLO20876.

Girardin, M.-P., Tardif, J., Flannigan, M.D., Wotton, B.M. and Bergeron, Y., 2004. Trends and periodicities in the Canadian Drought Code and their relationships with atmospheric circulation for the southern Canadian boreal forest. Canadian Journal of Forest Research. 34(1), 103-119.

Goetz, S.J., Bunn, A.G., Fiske, G.J. and Houghton, R.A., 2005. Satellite-observed photosynthetic trends across boreal North America associated with climate and fire disturbance. Proceedings of the National Academy of Sciences of the United States of America. 102(38), 13521-13525.

Goldammer, J.G., 2003. The wildland fire season 2002 in the Russian Federation: An assessment by the Global Fire Monitoring Center (GFMC). International Forest Fire News. 28, 2-14.

Goldammer, J.G., Sukhinin, A.I. and Csiszar, I.A., 2003. The current fire situation in the Russian Federation: Implications for enhancing international and regional cooperation in the UN framework and the global programs on fire monitoring and assessment. International Forest Fire News. 29, 89-111.

Greenbank, D.O., 1963. Climate and the spruce budworm. Memoirs Entomological Society Canada. 31, 174-180.

Groisman, P.Y., Sherstyukov, B.G., Razuvaev, V.N., Knight, R.W., Enloe, J.G., Stroumentova, N.S., Whitfield, P.H., Forland, E., Hannsen-Bauer, I., Tuomenvirta, H., Aleksandersson, H., Mescherkaya, A.V. and Karl, T.R., in press. Potential forest fire danger over Northern Eurasian: Changes during the 20th century. Global and Planetary Change, this issue.

Guisan, A., Holten, J.I., Spichiger, R. and Tessier, L., 1995. Potential Ecological Impacts of Climate Change in the Alps and Fennoscandian Mountains, Geneve, pp. 195.

Haines, D.A., 1988. A lower atmospheric severity index for wildland fires. National Weather Digest. 13, 23-27. 
Hansen, J.R., Fung, I., Lacis, A., Lebedef, S., Rind, D., Ruedy, R., Russel, G. and Stone, P., 1988. Global climate changes as forecast by the Goddard Institute for Space Studies three dimensional model. Journal of Geophysical Research. 93, 9341-9364.

Hansen, J.R., Ruedy, M., Sato, M. and Reynolds, R., 1996. Global surface air temperature in 1995: Return to pre-Pinatubo level. Geophysical Research Letters. 23, 1665-1668.

Harden, J.W., Trumbore, S.E., Stocks, B.J., Hirsch, A., Gower, S.T., O'Neill, K.P. and Kasischke, E.S., 2000. The role of fire in the boreal carbon budget. Global Change Biology. 6, 174-184.

Hare, F.K. and Ritchie, J.C., 1972. The boreal bioclimates. Geographical Review. 62, 333365.

Harrington, J.B., Flannigan, M.D. and Van Wagner, C.E., 1983. A study of the relationship of components of the Fire Weather Index to monthly provincial area burned by wildfire in Canada. Rep. PI-X-25, CFS Petawawa Natl. For. Inst. Inf.

Heinselman, 1978. Fire intensity and frequency as factors in the disturbance and structure of northern ecosystems. In: H.A. Mooney, T.M. Bonnicksen, N.L. Christensen, J.E. Lotan and W.A. Reiners (Editors), Fire Regimes and Ecosystem Properties. USDA GTR WO-26, Honolulu, pp. 7-57.

Heinselman, M.L., 1981. Fire and succession in the conifer forests of northern North America. In: D.C. West, H.H. Shugart and D.B. Botkin (Editors), Forest Succession: Concepts and Application. Springer-Verlag, New York, pp. 374-405.

Hinzman, L.D., Bettez, N., Chapin, F.S., III, Dyurgerov, M., Fastie, C.L., Griffith, B., Hollister, R.D., Hope, A., Huntington, H.P., Jensen, A., Kane, D., Klein, D.R., Lynch, A., Lloyd, A.H., McGuire, A.D., Nelson, F., Oechel, W.C., Osterkamp, T., Racine, C., Romanovsky, V.E., Stow, D., Sturm, M., Tweedie, C.E., Vourlitis, G., Walker, M., Walker, D.A., Webber, P.J., Welker, J.M., Winker, K. and Yoshikawa, K., in press. Evidence and implications of recent climate change in terrestrial regions of the Arctic. Climatic Change.

Huston, M., DeAngelis, D.L. and Post, W.M., 1988. New computer models unify ecological theory. Bioscience. 38, 682-691.

IPCC, 1996. Climate Change 1995: The Science of Climate Change. Contribution of Working Group I to the Second Assessment Report of the Intergovernmental Panel on Climate Change. Cambridge University Press, New York, USA, pp. 572.

IPCC, 2001. Climate Change 2001: The Scientific Basis. Contribution of Working Group I to the Third Assessment Report of the Intergovernmental Panel on Climate Change.

Cambridge University Press, New York, USA, pp. 881.

Istomov, S.V., 2005. The current dynamics of the upper treeline in West Sayan mountains, Actual questions of research and protection of the plant world. Transactions of the Reserve "Tigiretky", pp. 211-214.

Johnson, E.A., 1992. Fire and Vegetation Dynamics: Studies from the North American Boreal Forest. Cambridge studies in ecology. Cambridge University Press, Cambridge, New York, pp. 125.

Jorgenson, M.T., Racine, C.H., Walters, J.C. and Osterkamp, T.E., 2001. Permafrost degradation and ecological changes associated with a warming climate in central Alaska. Climatic Change. 48(4), 29.

Juday, G.P., Barber, V., S., R., Zasada, J. and M.W., W., 2003. A 200-year perspective of climate variability and the response of white spruce in Interior Alaska. In: D. Greenland, 
D. Goodin and R. Smith (Editors), Climate Variability and Ecosystem Response at LongTerm Ecological Research (LTER) Sites. Oxford University Press, pp. 226-250.

Kasischke, E.S., Rupp, T.S. and Verbyla, D.L., 2006. Fire trends in the Alaskan boreal forest region. In: F.S. Chapin, III, M. Oswood, K.V. Cleve, L.A. Viereck and D.L. Verbyla (Editors), Alaska's Changing Boreal Forest. Oxford University Press, Oxford, pp. 285-301. Kasischke, E.S. and Stocks, B.J., 2000. Fire, Climate Change, and Carbon Cycling in the Boreal Forest. Ecological Studies 138. Springer-Verlag, New York, pp. 461.

Keyser, A.R., Kimball, J.S., Nemani, R.R. and Running, S.W., 2000. Simulating the effects of climatic change on the carbon balance of North American high-latitude forests. Global Change Biology 6 (Suppl. 1), 185-195.

Korovin, G.N., 1996. Analysis of the distribution of forest fires in Russia. In: J.G. Goldammer and V.V. Furyaev (Editors), Fire in Ecosystems of Boreal Eurasia. Kluwer Academic Publishers, Dordrecht, pp. 112-128.

Kurz, W.A., Apps, M.J., Stocks, B.J. and Volney, W.J.A., 1995. Global climate change: Disturbance regimes and biospheric feedbacks of temperate and boreal forests. In: G.M. Woodwell and F.T. MacKenzie (Editors), Biotic Feedbacks in the Global Climate System: Will the Warming Feed the Warming? Oxford University Press, New York, pp. 119-133.

Larsen, J.A., 1980. The Boreal Ecosystem. Physiological ecology. Academic Press, New York, pp. 500.

Lloyd, A.H. and Fastie, C.L., 2002. Spatial and Temporal Variability in the Growth and Climate Response of Treeline Trees in Alaska. Climatic Change. 52(4), 29.

Logan, J.A., Regniere, J. and Powell, J.A., 2003. Assessing the impacts of global warming on forest pest dynamics. Frontiers in Ecology and the Environment. 1, 130-137.

Loucks, O.L., 1970. Evolution of diversity, efficiency, and community stability. American Zoologist. 10, 17-25.

Lutz, H.J., 1956. Ecological Effects of Forest Fires in the Interior of Alaska. Tech. Bull. 1133, US Department of Agriculture, Washington.

Lydolph, P.E., 1985. The Climate of the Earth. Rowman and Allanheld, Totowa, New Jersey, pp. 386.

MacLean, D.A., Woodley, S.J., Weber, M.G. and Wein, R.W., 1983. Fire and nutrient cycling. In: R.W. Wein and D.A. MacLean (Editors), The Role of Fire in Northern Circumpolar Ecosystems. John Wiley and Sons, New York, pp. 111-132.

Manabe, S. and Wetherald, R.T., 1987. Large scale changes in soil wetness induced by an increase in carbon dioxide. Journal of Atmospheric Sciences. 44, 1211-1235.

Mann, M.E., Bradley, R.S. and Hughes, M.K., 1999. Northern Hemisphere temperatures during the past millennium: Inferences, uncertainties, and limitations. Geophysical Research Letters. 26(6), 759-762.

Mattson, W.J. and Haack, R.A., 1987. The role of drought in outbreaks of plant-eating insects. Bioscience. 37(2), 110-118.

McGuire, A.D., Melillo, J.W., Kicklighter, D.W. and Joyce, L.A., 1995. Equilibrium responses of soil carbon to climate change: Empirical and process-based estimates. Journal of Biogeography. 22, 785-796.

Mikhailov, N.N. and Ostanin, O.A., 2001. Glaciers changes of Southern Altai during the 20th century, Natural conditions, history and culture of West Mongolia and adjacent regions. Tomsk State University Publishers, Tomsk, pp. 20-21. 
Moiseev, P.A., 2002. Climate change impacts on radial growth and formation of the age structure of highland larch forests in Kuznetsky Alatau. Russian Journal of Ecology. 1, 1016.

Myneni, R.B., Keeling, C.D., Tucker, C.J., Asrar, G. and Nemani, R.R., 1997. Increased plant growth in the northern high latitudes from 1981 to 1991. Nature. 386(6626), 4.

Narozhnyi, Y.K., Nikitin, V.V., Paromov, A.V., Osipov, A.V. and Lukianov, A.A., 2002. The glacier Sofiisky (Altai): A dynamics, glacial- and hydroclimatic regimes and ice volume distribution. Transactions of glacial research. 93, 107-122.

National Assessment Synthesis Team, 2001. Climate Change Impacts on the United States: The Potential Consequences of Climate Variability and Change. Foundation Report, US Global Change Research Program, Washington, D.C.

Nesterov, V.G., 1949. Combustibility of the forest and methods for its determination, USSR State Industry Press.

Neuvonen, S., Niemela, P. and Virtanen, T., 1999. Climatic change and insect outbreaks in boreal forsts: The role of winter tempertures. Ecological Bulletins. 47, 63-67.

Noskova, N.E., Pomanova, L.I. and Tretiakova, I.N., 2004. Peculiarities of generative processes of Siberian conifers in relation with climatic changes. Bulletin of Tomsk State University. 10, 78-81.

Ovchinnikov, D.V. and Vaganov, E.A., 1999. Dendrochronological characteristics of Larix sibirica L. at the upper tree line in Mountain Altai. Siberian Ecological Journal. 2, 145152.

Ovchinnikova, N.F. and Ermolenko, P.M., 2004. Long-term forest vegetation inventories in West Sayan mountains. World Resource Review.

Overpeck, J.T., Rind, D. and Goldberg, R., 1990. Climate-induced changes in forest disturbance and vegetation. Nature. 343, 51-53.

Parfenova, E.I. and Tchebakova, N.M., 2000. Possible vegetation change in Mountain Altai under climate warming and predicted maps. Geobotanical mapping, 1998-2000, 26-31.

Payette, S., Delwaide, A., Caccianiga, M. and Beauchemin, M., 2004. Accelerated thawing of subarctic peatland permafrost over the last 50 years. Geophysical Research Letters. 31(18), DOI 10 1029/2004GLO20358.

Podur, J., Martell, D. and Knight, K., 2002. Statistical quality control analysis of forest fire activity in Canada. Canadian Journal of Forest Research. 32(2), 195-205.

Polozhiy, A.V. and Krapivkina, E.D., 1985. Relics of Tertiary deciduous forests in Siberian flora. Tomsk State University Publishers, Tomsk, pp. 158.

Pozdnyakov, L.K., 1993. Forest science on permafrost. Nauka, Novosibirsk, pp. 192.

Price, C. and Rind, D., 1994. Possible implications of global climate change on global lightning distributions and frequencies. Journal of Geophysical Research. 99(D5), 1082310831 .

Rizzo, B. and Wilken, E., 1992. Assessing the sensitivity of Canada's forest to climatic change. Climate Change. 21, 37-55.

Rowe, J.S. and Scotter, G.W., 1973. Fire in the boreal forest. Quarternary Research. 3, 444464.

Rupp, T.S., Chapin, F.S., III and Starfield, A.M., 2000. Response of subarctic vegetation to transient climatic change on the Seward Peninsula in northwest Alaska. Global Change Biology. 6, 451-455. 
Serreze, M.C., Walsh, J.E., F. S. Chapin, I., Osterkamp, T., Dyurgerov, M., Romanovsky, V., Oechel, W.C., Morison, J., Zhang, T. and Barry, R.G., 2000. Observational evidence of recent change in the northern high-latitude environment. Climate Change. 46, 159-207.

Sharkhuu, N., 2003. Permafrost study. Dynamics of biodiversity loss and permafrost melt in Lake Hovsgol National Park, Mongolia, 2003 Annual Report, GEF/World Bank, UlanBaatar.

Shiyatov, S.G., Mazepa, V.S., Moiseev, P.A. and Bratukhina, M.Y., 2001. Climate change and its impacts on mountain ecosystems of National Park "Taganai" during the last centuries. In: A. Kokorin, A. Kojarinov and A. Minin (Editors), Climate change impacts on ecosystems. Protected natural territories of Russia: Analyses of long-term observations, Moscow.

Shugart, H.H., 1998. Terrestrial ecosystems in changing environments. Cambridge studies in ecology. Cambridge University Press, New York, pp. xiv, 537.

Shugart, H.H., Clark, D.F. and Hill, A.J., 2000. Ecological models of the dynamics of boreal landscapes. In: E.S. Kasischke and B.J. Stocks (Editors), Fire, Climate Change, and Carbon Cycling in the Boreal Forest. Springer-Verlag, New York, pp. 389-405.

Shugart, H.H., Leemans, R. and Bonan, G.B., 1991. A Systems Analysis of the Global Boreal Forest. Cambridge University Press, New York, pp. 565.

Shugart, H.H. and West, D.C., 1980. Forest succession models. Bioscience. 30, 308-313.

Shumilova, L.V., 1962. Botanical Geography of Siberia. Tomsk University Press, Tomsk, pp. 440.

Shvidenko, A. and Goldammer, J.G., 2001. Fire situation in Russia. International Forest Fire News. 24, 41-59.

Shvidenko, A.Z. and Nilsson, S., 2000. Extent, distribution, and ecological role of fire in Russian forests. In: E.S. Kasischke and B.J. Stocks (Editors), Fire, Climate Change, and Carbon Cycling in the Boreal Forest. Ecological Studies 138. Springer-Verlag, New York, pp. 132-150.

Smith, T.M. and Shugart, H.H., 1993a. The potential response of global terrestrial carbon storage to a climate change. Water Air and Soil Pollution. 70(1-4), 629-642.

Smith, T.M. and Shugart, H.H., 1993b. The transient response of terrestrial carbon storage to a perturbed climate. Nature. 361, 523-526.

Sofronov, M.A., Volokitina, A.V. and Schvidenko, A.Z., 1998. Wildland fires in the north of Central Siberia. Commonwealth Forestry Review. 77(2), 124-127.

Soja, A.J., Cofer III, W.R., Shugart, H.H., Sukhinin, A.I., Stackhouse Jr., P.W., McRae, D.J. and Conard, S.G., 2004a. Estimating fire emissions and disparities in boreal Siberia (1998 through 2002). Journal of Geophysical Research. 109(D14S06), doi:10.1029/2004JD004570.

Soja, A.J., Sukhinin, A.I., Cahoon, D.R., Jr., Shugart, H.H. and Stackhouse, P.W., Jr., 2004b. AVHRR-derived fire frequency, distribution and area burned in Siberia. International Journal of Remote Sensing. 25(10), 1939-1960.

Solomon, A.M., Delcourt, D.C., West, D.C. and Blasing, T.J., 1980. Testing a simulation model for reconstruction of prehistoric forest-stand dynamics. Quaternary Research. 14, 275-293.

Solomon, A.M. and Webb III, T., 1985. Computer-aided reconstruction of late Quaternary landscape dynamics. Annual Review of Ecology and Systematics. 16, 63-84. 
Starfield, A.M. and Chapin, F.S., III, 1996. Model of transient changes in arctic and boreal vegetation in response to climate and land use change. Ecological Applications. 6, 842864.

Stocks, B.J., Fosberg, M.A., Lynham, T.J., Mearns, L., Wotton, B.M., Yang, Q., Jin, J.Z., Lawrence, K., Hartley, G.R., Mason, J.A. and McKenney, D.W., 1998. Climate change and forest fire potential in Russian and Canadian boreal forests. Climatic Change. 38(1), 113.

Stocks, B.J., Fosberg, M.A., Wotton, M.B., Lynham, T.J. and Ryan, K.C., 2000. Climate change and forest fire activity in North American boreal forests. In: E.S. Kasischke and B.J. Stocks (Editors), Fire, Climate Change, and Carbon Cycling in the Boreal Forest. Springer-Verlag, New York, pp. 368-376.

Stocks, B.J. and Lynham, T.J., 1996. Fire weather climatology in Canada and Russia. In: J.G. Goldammer and V.V. Furyaev (Editors), Fire in Ecosystems of Boreal Eurasia. Kluwer Academic Publishers, Boston, pp. 481-494.

Stocks, B.J., Mason, J.A., Todd, J.B., Bosch, E.M., Wotton, B.M., Amiro, B.D., Flannigan, M.D., Hirsch, K.G., Logan, K.A., Martell, D.L. and Skinner, W.R., 2002. Large forest fires in Canada, 1959-1997. Journal of Geophysical Research.

Stocks, B.J. and Street, R.B., 1982. Forest fire weather and wildfire occurrence in the boreal forest of northwestern Ontario. In: R.W. Wein, R.R. Riewe and I.R. Methuen (Editors), Resources and Dynamics of the Boreal Zone. Association of Universities of Canadian Universities for Northern Studies, Ottawa, Canada, pp. 249-265.

Street, R.B., 1989. Climate change and forest fires in Ontario, 10th Conference on Fire and Forest Meteorology, Ottawa, Canada, pp. 177-182.

Sturm, M., Racine, C. and Tape, K., 2001. Climate change: Increasing shrub abundance in the Arctic. Nature. 411(6837), 546-547.

Sukhinin, A.I., French, N.H.F., Kasischke, E.S., Hewson, J.H., Soja, A.J., Csiszar, I.A., Hyer, E.J., Loboda, T., Conard, S.G., Romasko, V.I., Pavlichenko, E.A., Miskiv, S.I. and Slinkina, O.A., 2004. AVHRR-based mapping of fires in Russia: New products for fire management and carbon cycle studies. Remote Sensing of Environment. 93, 546-564.

Swetnam, T.W., 1993. Fire history and climate change in giant Sequois groves. Science. 262, 885-889.

Tape, K., 2004. Shrub Expansion in Arctic Alaska: 50 Years of Change Documented Using Aerial Photography. MS Thesis, University of Alaska, Fairbanks,

Tchebakova, N.M., Monserud, R.A. and Parfenova, E.I., 2001. Phytomass change in the mountain forests of southern Siberia under climate warming In: Proceedings of the First National Conference on Carbon Sequestration. CD: DOE/NETL-2001/1144.

Tikhomirov, B.A., 1963. Principle stages of vegetation development in northern USSR as related to climatic fluctuations and the activity of man. Canadian Geographer. 7, 55-71.

Timoshok, E.E., Naroznyi, Y.K., Dirks, M.N. and Berezov, A.A., 2003. Experience in combined glaciological and botanical studies on the primary plant successions on young moraines in the Central Altai. Russian Journal of Ecology. 34(2), 91-97.

Tumel, V.F., 1939. Changes in the soils and permafrost regimes following vegetation cover burning. Reports of the Permafrost Commission, Issue VIII, Academy of Sciences of the USSR, Moscow-Leningrad. 
U.S. Department of Agriculture, 2005. Forest Health Conditions in Alaska - 2004: A forest health protection report. R10-PR-3, USDA Forest Service Alaska Region, Anchorage, Alaska.

Van Cleve, K. and Viereck, L.A., 1981. Forest succession in relation to nutrient cycling in the boreal forest of Alaska. In: D.C. West, D.B. Botkin and H.H. Shugart (Editors), Forest Succession: Concepts and Application. Springer advanced texts in life sciences. SpringerVerlag, New York, pp. 185-211.

Van Cleve, K. and Viereck, L.A., 1983. A comparison of successional sequences following fire on permafrost-dominated and permafrost-free sites in interior Alaska, Permafrost: Proceeding of the Fourth International Conference. National Academy Press, Fairbanks, Alaska, pp. 1286-1291.

Van Wagner, C.E., 1978. Age class distribution and the forest fire cycle. Canadian Journal of Forest Research. 8, 220-227.

Van Wagner, C.E., 1987. Development and Structure of the Canadian Forest Fire Weather Index System. For. Tech. Rep. 35, Canadian Forest Service.

Van Wagner, C.E., 1988. The historical pattern of annual area burned in Canada. For. Chron. 64, 182-185.

Viereck, L.A. and Schandelmeier, L.H., 1980. Effects of Fire in Alaska and Adjacent Canada - A Literature Review. BLM TR 6, US Department of the Interior, Bureau of Land Management, Alaska, Fairbanks.

Vlasenko, V.I., 2000. Mapping vegetation dynamics of the Sayan-Shush Reserve. Geobotanical Mapping, 1998-2000, 32-49.

Vlassova, T.K., 2002. Human impacts on the tundra-taiga zone dynamics: The case of the Russian lesotundra. Ambio Special Report (Tundra-Taiga Treeline Research). 12, 30-36.

Volney, W.J.A. and Fleming, R.A., 2001. Climate change and impacts of boreal forest insects. Agriculture, ecosystems \& environment. 82(1), 283-294.

Walter, H., 1979. Vegetation of the Earth and Ecological Systems of the Geo-biosphere. Springer-Verlag, New York, pp. 274.

Weber, M.G. and Flannigan, M., 1997. Canadian boreal forest ecosystem structure and function in a changing clime: Impact on fire regimes. Environmental Reviews. 5, 145-166.

Werner, R.A., Raffa, K.F. and Illman, B.L., 2005. Dynamics of phytophagous insects and their pathogens in Alaskan boreal forests. In: F.S. Chapin III, M. Oswood, K.V. Cleve, L.A. Viereck and D.L. Verbyla (Editors), Alaska's Changing Boreal Forest. Oxford University Press, Oxford.

West, D.C., Botkin, D.B. and Shugart, H.H., 1981. Forest Succession: Concepts and Application. Springer advanced texts in life sciences. Springer-Verlag, New York, pp. 517.

Williams, D.W. and Liebhold, M., 1995. Herbivorous insects and global change: potential changes in spatial distribution of forest defoliators. Journal of Biogeography. 22, 665-671.

Wilmking, M., Juday, G.P., Barber, V.A. and Zald, H.S.J., 2004. Recent climate warming forces contrasting growth responses of white spruce at treeline in Alaska through temperature thresholds. Global Change Biology. 10(10), 1724-1736.

Wotton, B.M. and Flannigan, M.D., 1993. Length of the fire season in a changing climate. Forestry Chronicle. 69(2), 187-192.

Wotton, B.M., Martell, D.L. and Logan, K.A., 2003. Climate change and people-caused forest fire occurrence in Ontario. Climatic Change. 60, 275-295. 
Zackrisson, O., 1977. Influence of forest fires on the North Swedish boreal forest. Oikos. 29, 22-32.

Zoltai, S.C. and Martikainen, P.J., 1996. The role of forested peatlands in the global carbon cycle. In: M.J. Apps and D.T. Price (Editors), Forest Ecosystems, Forest Management and the Global Carbon Cycle. NATO ASI. Springer-Verlag, Heidelberg, pp. 47-58. 


\section{Figure Captions}

Figure 1

Trends in climate over recent time. (A) Monthly trends in temperature over time. (B) Trend in annual precipitation over time. Reprinted with permission from the IPCC (2001).

Figure 2

Boreal biosphere interaction with climate.

Figure 3

Outbreak dynamics of the Siberian moth (Dendrolimus superans sibiricus) in Krasnojarsk, Siberia, reported in millions of hectares (M ha) of area damaged. Modified from

Baranchikov et al. (2002).

Figure 4

Area burned in Russia. Data for this graph was taken from several sources:

Forest Service - Ground data from the Russian Federal Forest Service (Shvidenko and

Goldammer, 2001; Goldammer, 2003; Goldammer et al., 2003);

Sukachev - Satellite-based data (Soja et al., 2004b; Sukhinin et al., 2004). These data are for Russian Siberia only, which extends from east of the Urals to the Far East coast. Fire in European Russia is estimated to be an average of $10 \%$ of the total area burned annually. The years 1996 and 1997 were originally processed with a different algorithm and then reprocessed to include larger fires with available AVHRR Local Area Coverage data; 1987 - Satellite-based data (Cahoon et al., 1994). Area burned estimates were calculated from only a portion of Siberia in the Amurskia and Chita regions;

1992 - Satellite-based data (Cahoon et al., 1996); and

1998 - Satellite-based data (Conard et al., 2002). 
For consistency, the linear regression is for the Russian Federal Forest Service data only.

Figure 5

Figure 5a Figure 5b

Satellite-derived fires in Siberia from 1995 through 2005.

Figure 6

Area burned annually in Canada reported in millions of hectares ( $\mathrm{M} \mathrm{ha})$. Note the increase in the number of extreme fire years over the last decades.

Figure 7

Large fires in Alaska and Canada from 1980 through 1999.

Figure 8

Area burned annually across North America reported in millions of hectares. Area burned is shown separately for Canada and Alaska and the cumulative area burned for North America is also shown. Note the recent increase in extreme fire years in Alaska, Canada and North America.

Figure 9

Vegetation distribution in Siberia: (A) current and (B) future (2100) based on a Hadley scenario (HadCM3GGal) (IPCC, 1996). Water (0), tundra (1), forest-tundra (2), northern dark taiga (3) and light taiga (4), middle dark taiga (5) and light taiga (6), southern dark taiga (7) and light taiga (8), forest-steppe (9), steppe (10), semidesert (11), broadleaved (12), temperate forest-steppe (13) and temperate steppe (14).

Figure10

Climate change over the Sayan Mountains: observations from 1980-2000 (left) and predicted (right) by a Hadley Centre scenario (HadCM3GGa1) for 2090. Winter temperatures have already 
exceeded 2090 model estimates, while summer temperatures have not. Patterns of precipitation are currently difficult to predict, particularly at the GCM scale.

Figure 11

Mean monthly temperatures recorded from the Davsha, Siberia station and projected mean monthly temperatures from a $2^{\circ} \mathrm{C}$ warmer scenario. Monthly temperatures cross the $5^{\circ} \mathrm{C}$ threshold twice, once in the spring and once in the fall. The warm days between these dates are used to determine long-term Growing Season length (GS). Even though GS is a function of temperature in all months, the GS can be approximated using January minimum and July maximum temperatures (positive degree days, L, defined in Table 1) or using the slope of the line, which results in an extension of the GS by 17.44 and 16.45 days, respectively, in this example.

Figure 12

Application of a gap model to predict the dynamic response of forests associated with the current climate and two different climate change scenarios for forests growing in the vicinity of Fairbanks, Alaska. a. The monthly temperature and precipitation for Fairbanks and equivalent information from the GISS (Hansen et al., 1988) and GFDL (Manabe and Wetherald, 1987) climate simulation models. Note the elevated winter temperatures in both models. b. Control case is the average of 100 gap models simulations for forest change over 150 years on north-facing slopes. The transition from the current climate to the new climate occurred incrementally over the first 50 years in the GISS and GFDL cases. The only tree species that occurs in these conditions is Black Spruce (Picea marina). The effect of the transition to a warmer $\mathrm{CO}_{2}$-effect climate is to slightly increase or have no effect on the simulated Black Spruce forest. c. Average of 100 gap model simulations of forest change 
over 150 years on south-facing slopes. The three species that normally occur in these settings (control case) are eliminated from these sites with climate warming. [Modified from Bonan (1988)]. 


\begin{tabular}{|c|c|c|c|c|c|c|c|}
\hline $\begin{array}{c}\text { Station, } \\
\text { (Lat, Lon, Alt) }\end{array}$ & $\mathrm{T}_{\mathrm{W}}$ & $? \mathrm{~T}_{\mathrm{W}}$ & $\mathrm{T}_{\mathrm{S}}$ & $? \mathrm{~T}_{\mathrm{S}}$ & $? \mathrm{~L}_{5}$ & $P_{a}$ & $? \mathrm{P}_{\mathrm{a}}$ \\
\hline \multicolumn{8}{|c|}{ The Urals (Shiyatov et al., 2001): Taganai $\left(55^{\circ} 22^{\prime} \mathrm{N}, 59^{\circ} 55^{\prime} \mathrm{E}, 1102 \mathrm{~m}\right)$} \\
\hline Before 1960 & -14.3 & & 12.3 & & \multirow[b]{2}{*}{+2.5} & 690 & \\
\hline 1961-1988 & -14.1 & +0.2 & 12.6 & +0.3 & & 955 & +265 \\
\hline \multicolumn{8}{|c|}{ Zlatoust $\left(55^{\circ} 10^{\prime} \mathrm{N}, 59^{\circ} 40^{\prime} \mathrm{E}, 457 \mathrm{~m}\right)$} \\
\hline Before 1960 & -15.5 & & 16.4 & & & 570 & \\
\hline $1961-1990$ & -14.5 & +1.0 & 16.5 & +0.1 & +2 & 710 & +140 \\
\hline 1991-1999 & -12.5 & +2.0 & 16.4 & -0.1 & +1.5 & 645 & -65 \\
\hline \multicolumn{8}{|c|}{ The Altai (Narojnyi et al., 2002; Yaskov et al., 2001): Kara-Tyurek $\left(49^{\circ} 35 \mathrm{~N}, 86^{\circ} 20^{\prime} \mathrm{E}, 2600 \mathrm{~m}\right)$} \\
\hline Before 1960 & -15.1 & & 5.2 & & \multirow[b]{2}{*}{+6} & 752 & \\
\hline 1961-1998 & -13.2 & +1.9 & 5.7 & +0.5 & & 882 & +130 \\
\hline \multicolumn{8}{|c|}{ Kosh-Agach $\left(50^{\circ} \mathrm{N}, 88^{\circ} 40^{\prime} \mathrm{E}, 1760 \mathrm{~m}\right)$} \\
\hline Before 1958 & -32.1 & & 12.0 & \multirow[b]{2}{*}{+0.3} & \multirow[b]{2}{*}{+7.5} & 110 & \\
\hline $1958-2000$ & -27.6 & +4.5 & 12.3 & & & 120 & +10 \\
\hline \multicolumn{8}{|c|}{$\begin{array}{l}\text { Mongun-Taiga (western Tyva), transient between the Altai and Sayan Mts: } \\
\text { Mugur-Aksy }\left(50^{\circ} 20^{\prime} \mathrm{N}, 90^{\circ} 25^{\prime} \mathrm{E}, 1860 \mathrm{~m}\right)\end{array}$} \\
\hline $1975-1990$ & -20.4 & & 13.2 & \multirow[b]{2}{*}{+1.1} & \multirow[b]{2}{*}{+9.5} & 165 & \\
\hline 1991-1999 & -19.7 & +0.7 & 14.3 & & & $170^{*}$ & +5 \\
\hline \multicolumn{8}{|c|}{ The Sayans : East Sayan, Krasnoyarsk $\left(56^{\circ} 04^{\prime} \mathrm{N}, 92^{\circ} 45^{\prime} \mathrm{E}, 276 \mathrm{~m}\right)$} \\
\hline Before 1960 & -17.1 & & 18.7 & & & 485 & \\
\hline $1961-1990$ & -16.0 & +1.1 & 18.4 & -0.3 & -1 & 485 & 0 \\
\hline 1991-1999 & -14.0 & +2.0 & 19.7 & +1.3 & +12.5 & 496 & +11 \\
\hline \multicolumn{8}{|c|}{ West Sayan, Yermaki $\left(53^{\circ} 20^{\prime} \mathrm{N}, 93^{\circ} 25^{\prime} \mathrm{E}, 300 \mathrm{~m}\right)$} \\
\hline Before 1960 & -19.3 & & 18.4 & & & 585 & \\
\hline $1961-1990$ & -18.1 & +1.2 & 18.4 & 0 & +1.5 & 550 & -35 \\
\hline 1991-1999 & -15.9 & +2.2 & 20.0 & +1.6 & +15 & 592 & +42 \\
\hline \multicolumn{8}{|c|}{ Oleniya Rechka $\left(52^{\circ} 48^{\prime} \mathrm{N}, 93^{\circ} 14^{\prime} \mathrm{E}, 1400 \mathrm{~m}\right)$} \\
\hline Before 1960 & -19.5 & & 12.3 & & & 1515 & \\
\hline $1961-1990$ & -18.0 & +1.5 & 12.1 & -0.2 & 0 & 1242 & -273 \\
\hline 1991-1999 & $-17.3^{*}$ & +0.7 & $13.6^{*}$ & +1.5 & +12.5 & $1156^{* * *}$ & - \\
\hline \multicolumn{8}{|c|}{ Transbaikalia (Ananin et al., 2001), Davsha $\left(52^{\circ} 20^{\prime} \mathrm{N}, 109^{\circ} 32^{\prime} \mathrm{E}, 489 \mathrm{~m}\right)$} \\
\hline Before 1960 & -23.2 & & 10.9 & & & 436 & \\
\hline $1961-1990$ & -23.1 & 0.1 & 12.2 & +1.3 & +10 & 402 & -34 \\
\hline 1991-1999 & -21.1 & +2.0 & 14.3 & +2.1 & +18.5 & 442 & +40 \\
\hline \multicolumn{8}{|c|}{ Mongolia (Nandintsetseg, 2003), Lake Hovsgol (about 50 $\mathrm{N}, 100^{\circ} \mathrm{E}, 1300-1650 \mathrm{~m}$ ) } \\
\hline $1970-2002$ & - & +3.2 & - & +2.4 & +22.5 & - & - \\
\hline
\end{tabular}

Table 1 Climate change data taken from ground stations across montane southern Siberia.

The purpose of these data are to demonstrate change over recent decades, as compared to earlier in the $20^{\text {th }}$ century $\left[\mathrm{T}_{\mathrm{W}}\right.$-temperature of January or winter (D-J-F) months; $\mathrm{T}_{\mathrm{S}}-$ temperature of July or summer (J-J-A) months; $\mathrm{P}_{\mathrm{a}}$ - annual precipitation; * - a 2-year break in the record; $* *$ - indicates 5 -year break in the record; $\mathrm{L}_{5}$ - days with continuous temperature above $5^{\circ} \mathrm{C}$ calculated from the formula found for 145 stations located throughout Siberia; $\mathrm{L}=$ $25.3+1.14\left(\mathrm{~T}_{\mathrm{W}}\right)+7.85\left(\mathrm{~T}_{\mathrm{S}}\right), \mathrm{R}^{2}=0.96$, std err 5.6 days. 

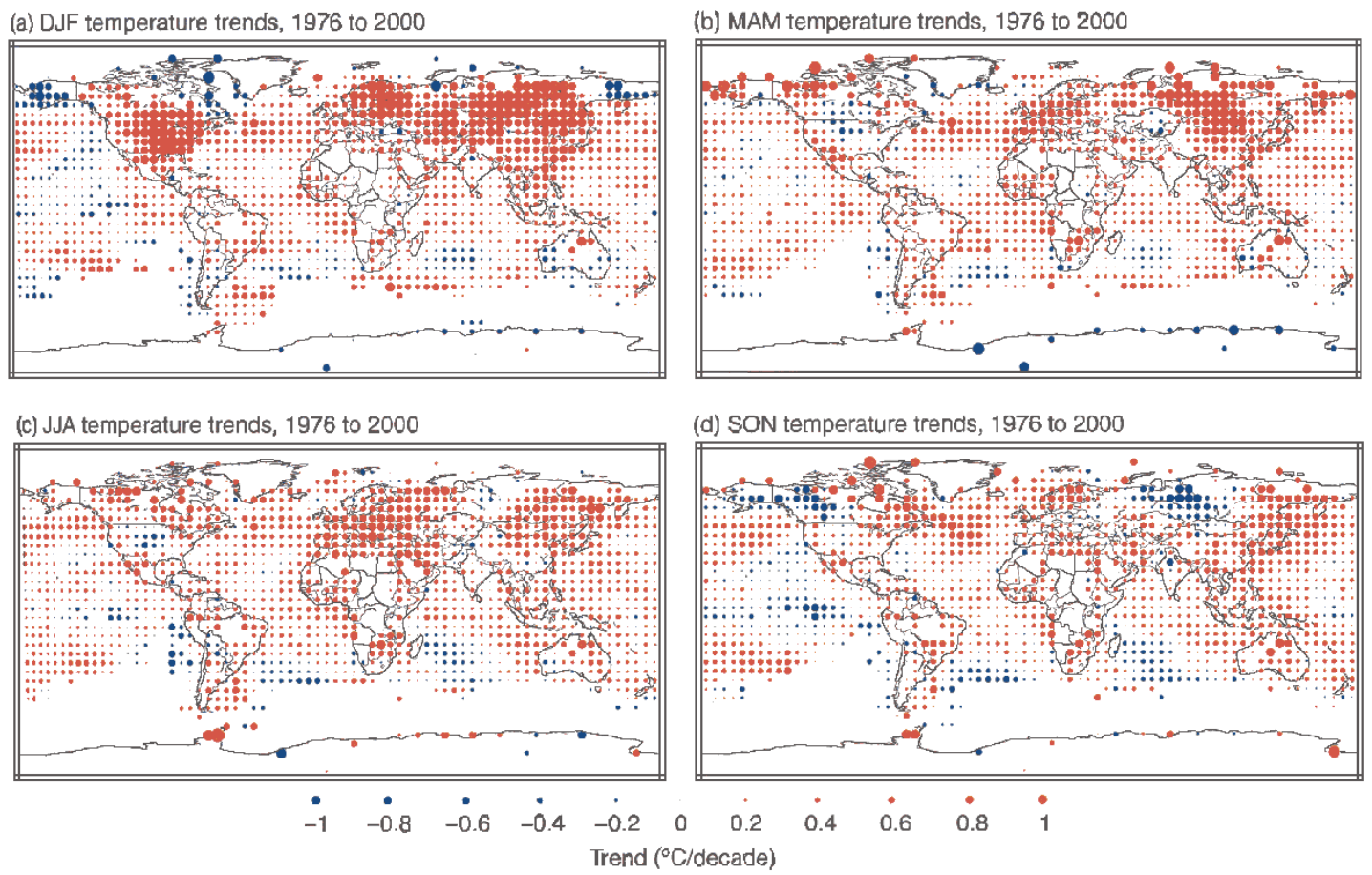

A.

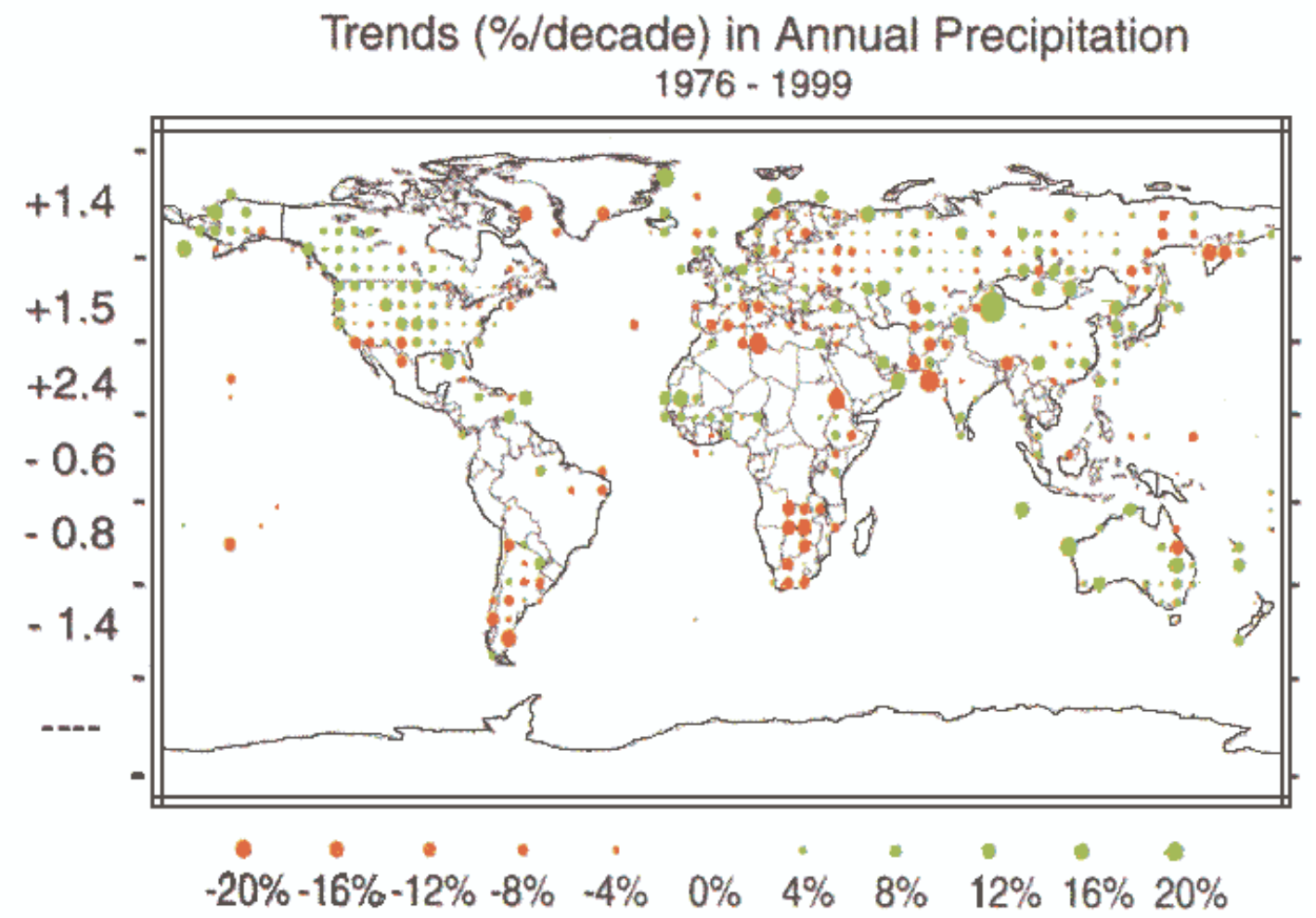

B.

Figure 1. Trends in climate over recent time. (A) Monthly trends in temperature over time. (B) Trend in annual precipitation over time. Reprinted with permission from the IPCC (2001). 


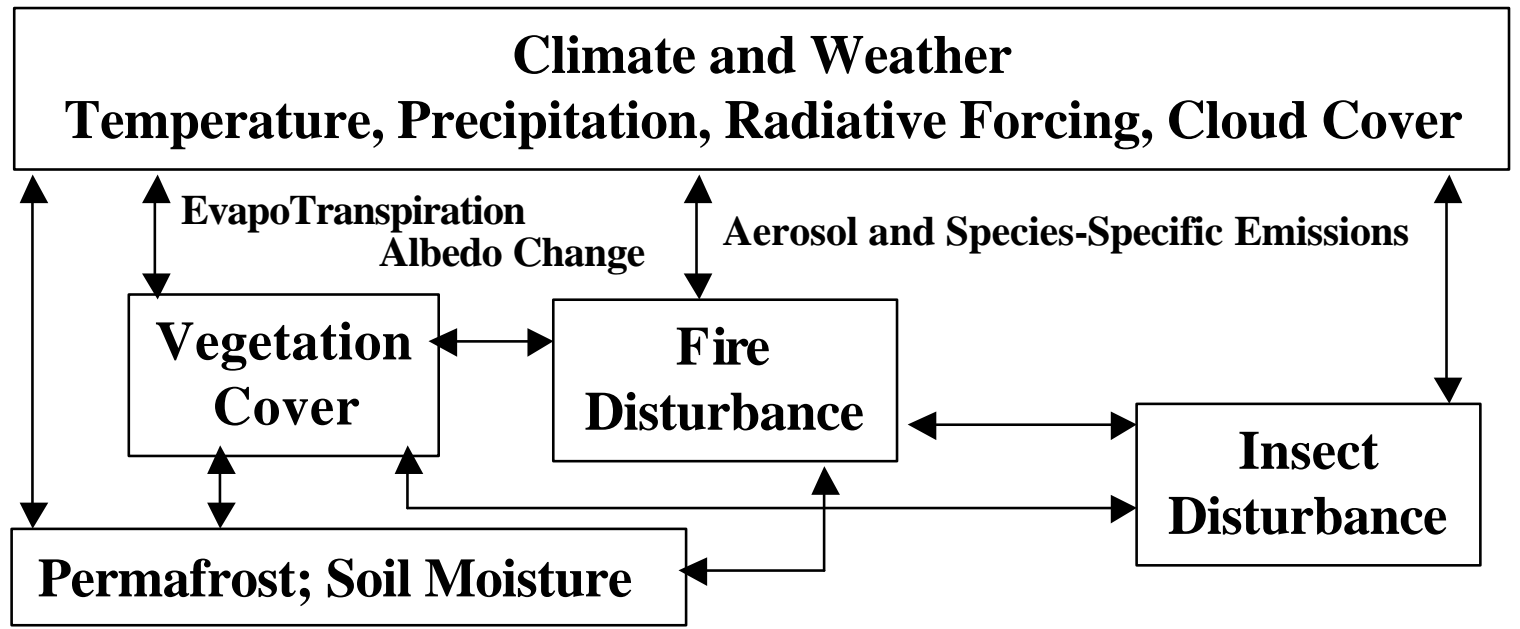

Figure 2

Boreal biosphere interaction with climate.

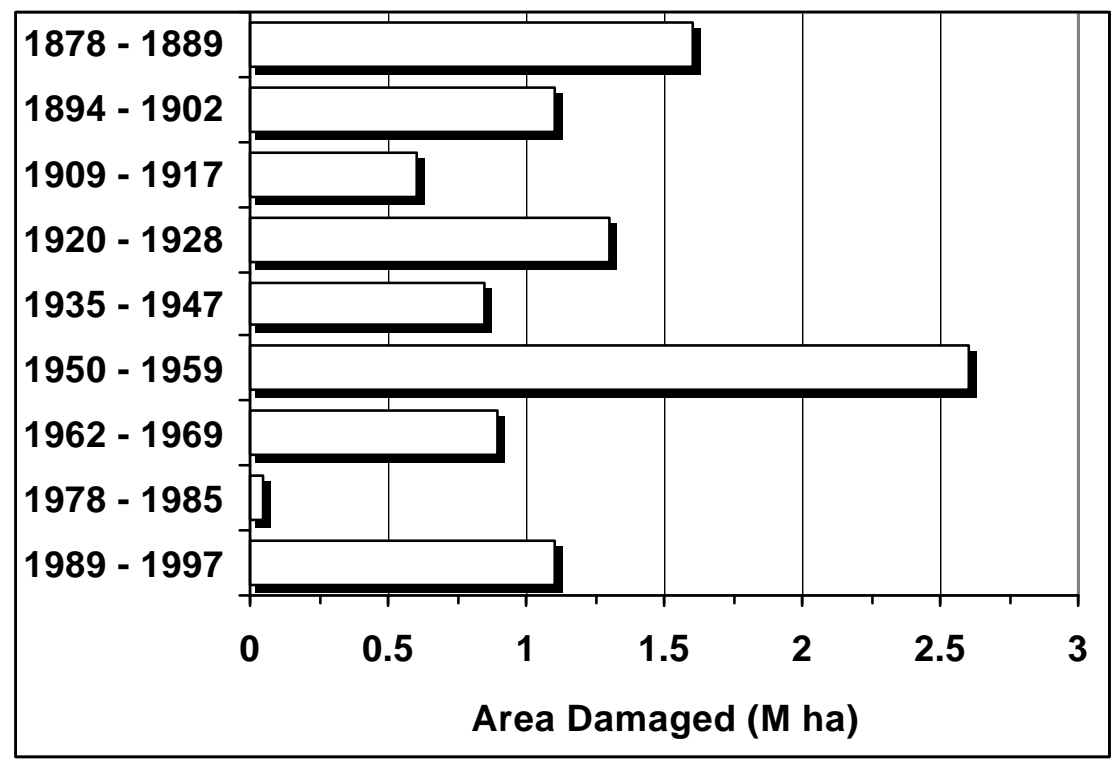

Figure 3

Outbreak dynamics of the Siberian moth (Dendrolimus superans sibiricus) in Krasnojarsk, Siberia, reported in millions of hectares ( $\mathrm{M}$ ha) of area damaged. Modified from Baranchikov et al. (2002). 


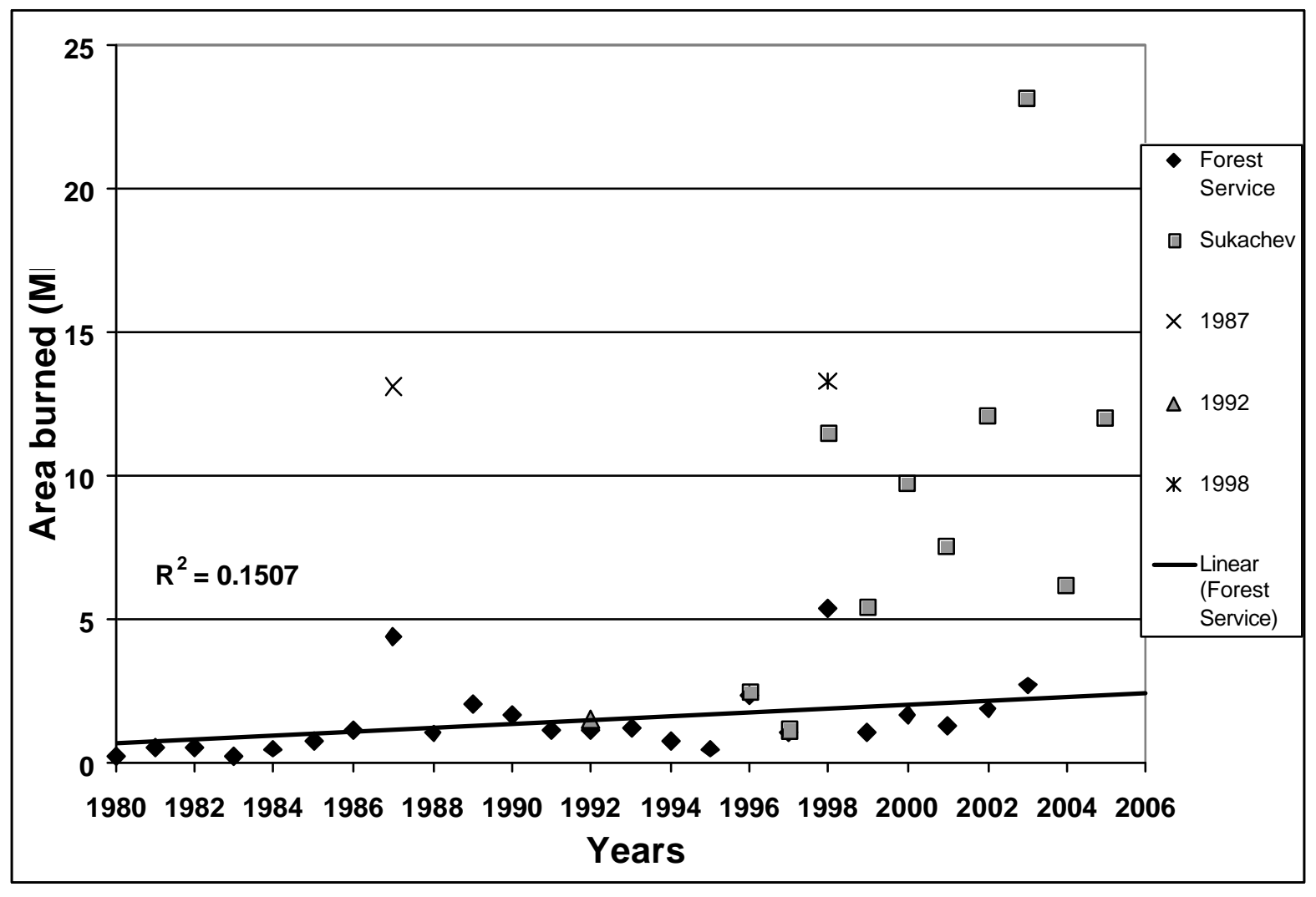

Figure 4

Area burned in Russia. Data for this graph was taken from several sources:

Forest Service - Ground data from the Russian Federal Forest Service (Shvidenko and Goldammer, 2001; Goldammer, 2003; Goldammer et al., 2003);

Sukachev - Satellite-based data (Soja et al., 2004b; Sukhinin et al., 2004). These data are for Russian Siberia only, which extends from east of the Urals to the Far East coast. Fire in European Russia is estimated to be an average of $10 \%$ of the total area burned annually. The years 1996 and 1997 were originally processed with a different algorithm and then reprocessed to include larger fires with available AVHRR Local Area Coverage data; 1987 - Satellite-based data (Cahoon et al., 1994). Area burned estimates were calculated from only a portion of Siberia in the Amurskia and Chita regions;

1992 - Satellite-based data (Cahoon et al., 1996); and

1998 - Satellite-based data (Conard et al., 2002).

For consistency, the linear regression is for the Russian Federal Forest Service data only. 


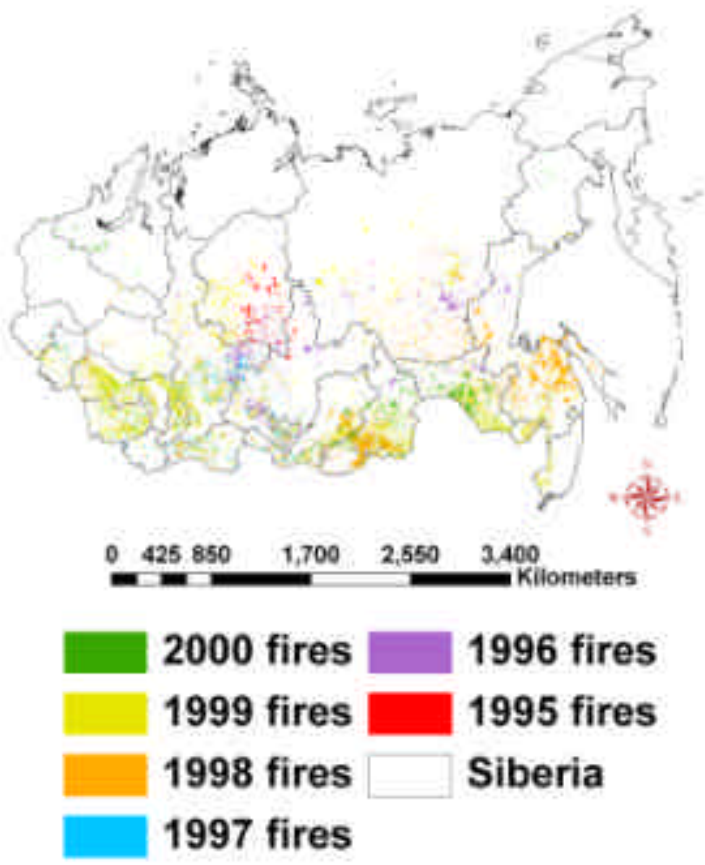

Figure 5a
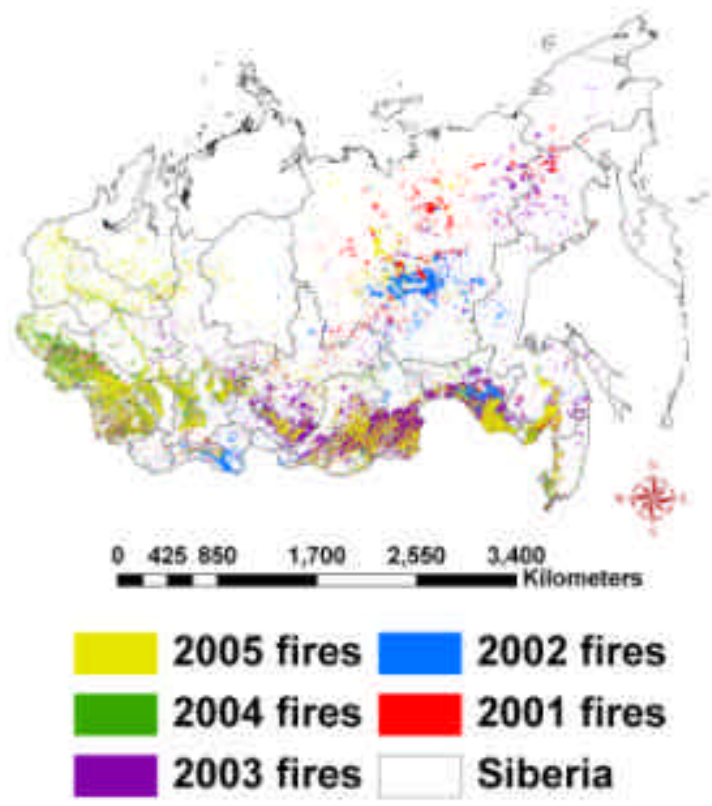

Figure $5 b$

Figure 5

Satellite-derived fires in Siberia from 1995 through 2005. 


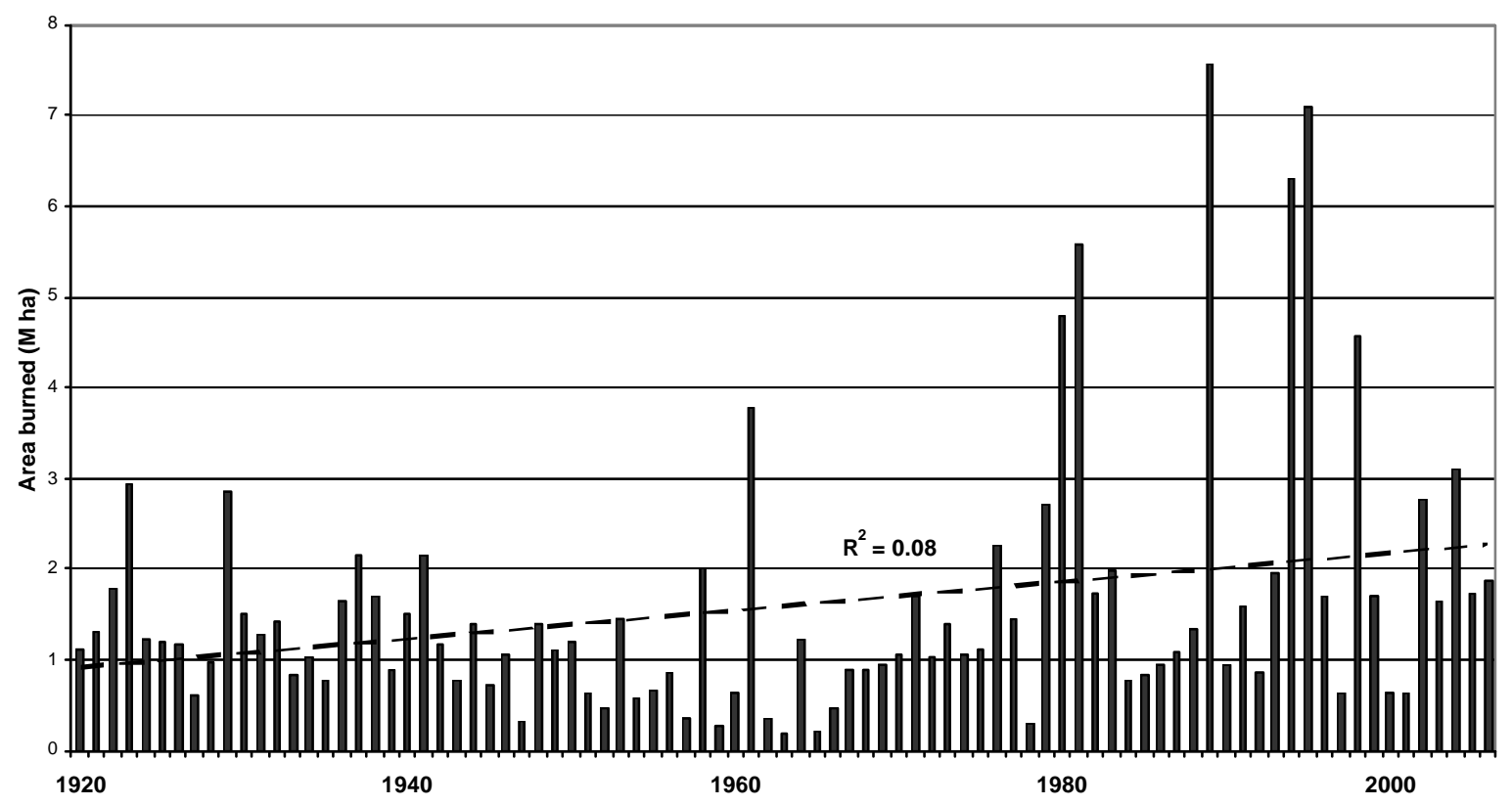

Figure 6

Area burned annually in Canada reported in millions of hectares ( $\mathrm{M}$ ha). Note the increase in the number of extreme fire years over the last decades.

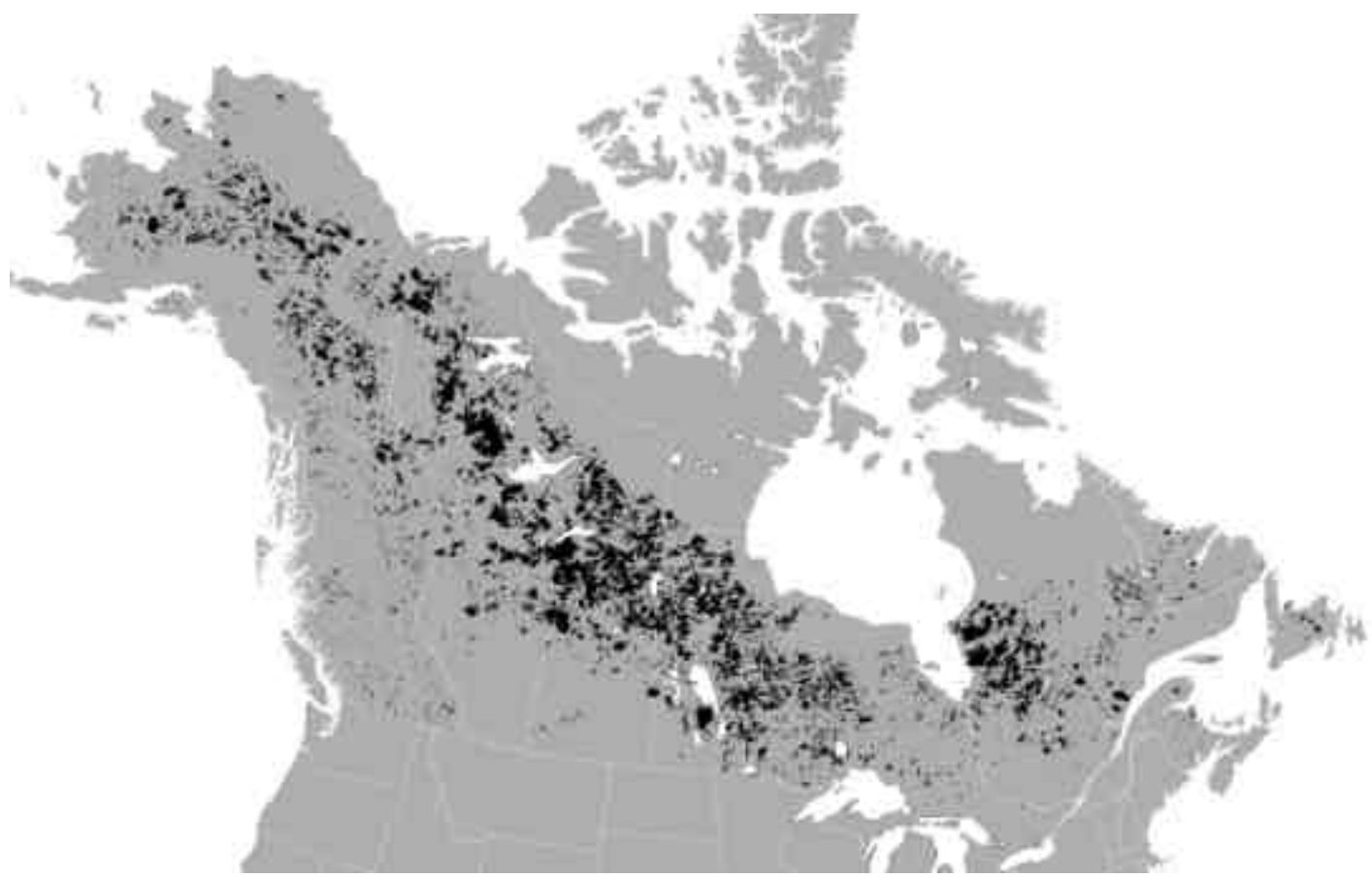

Figure $7 \quad$ Large fires in Alaska and Canada from 1980 through 1999. 


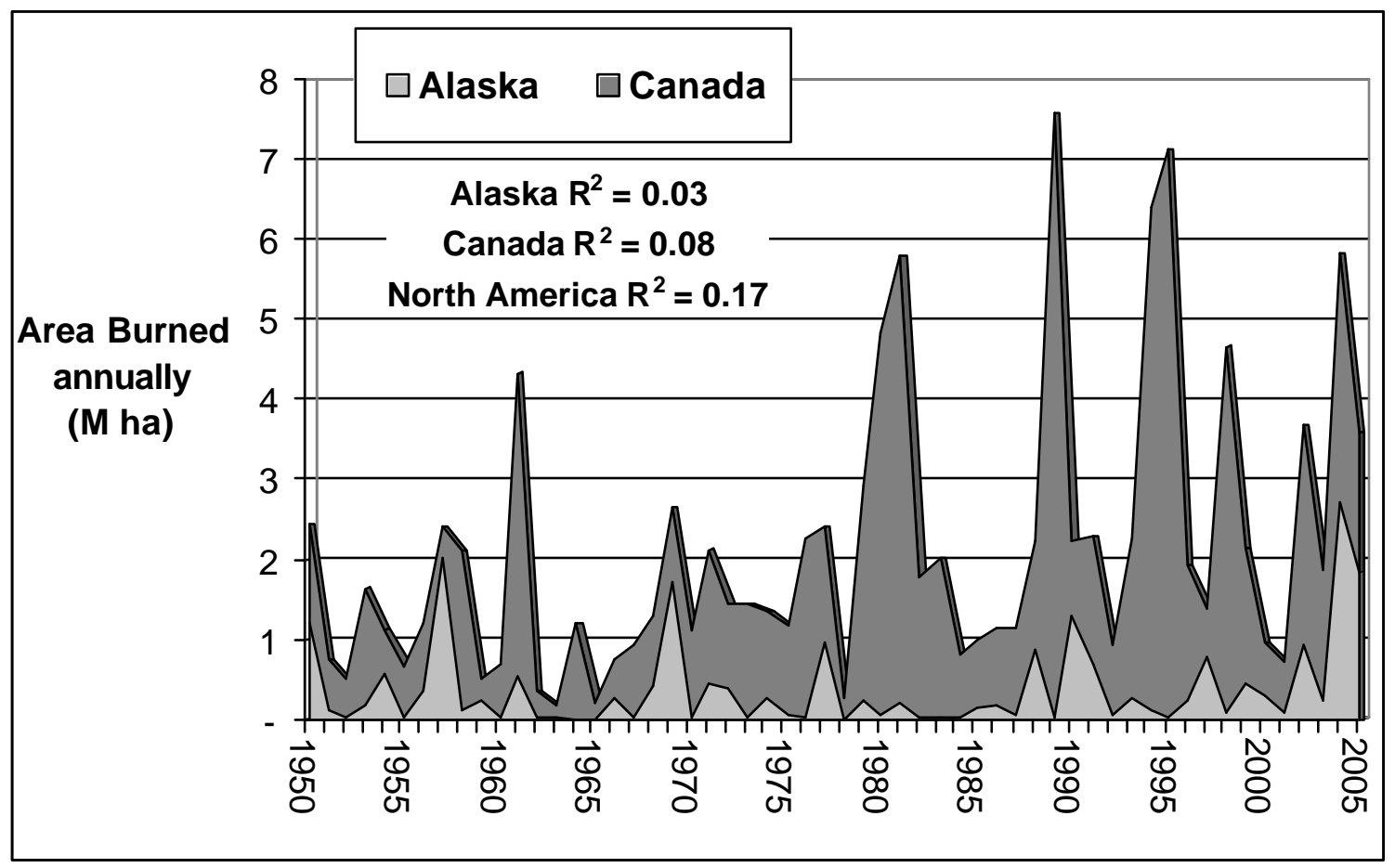

Figure 8

Area burned annually across North America reported in millions of hectares. Area burned is shown separately for Canada and Alaska and the cumulative area burned for North America is also shown. Note the recent increase in extreme fire years in Alaska, Canada and North America. 


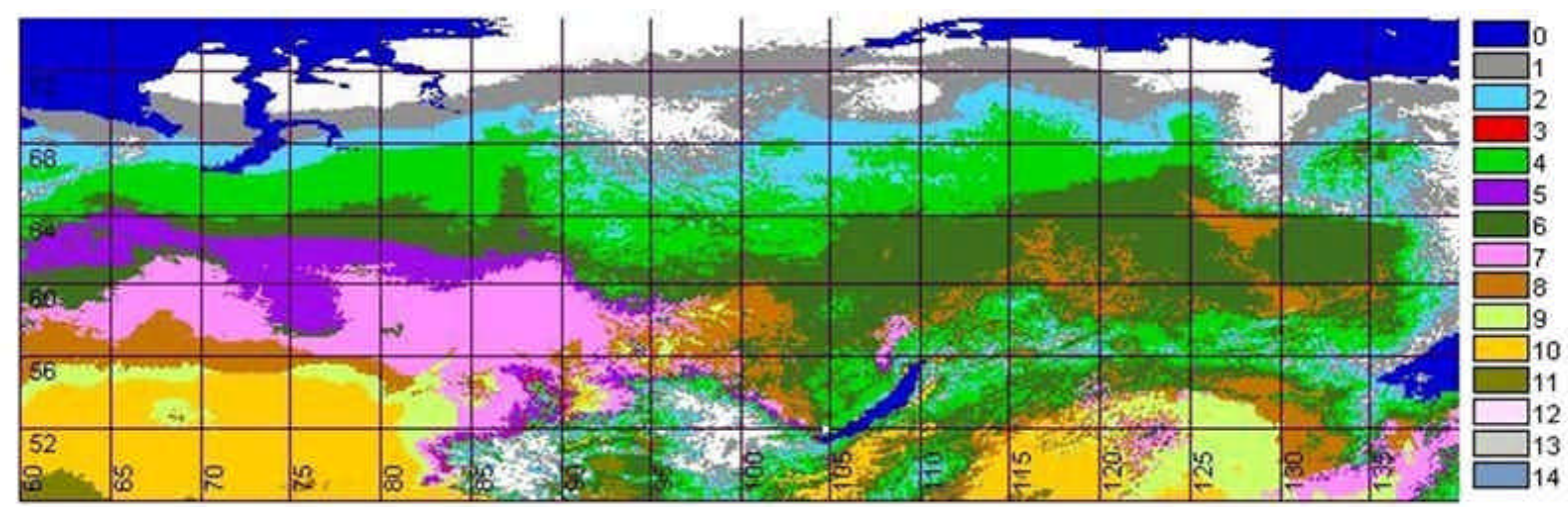

A.
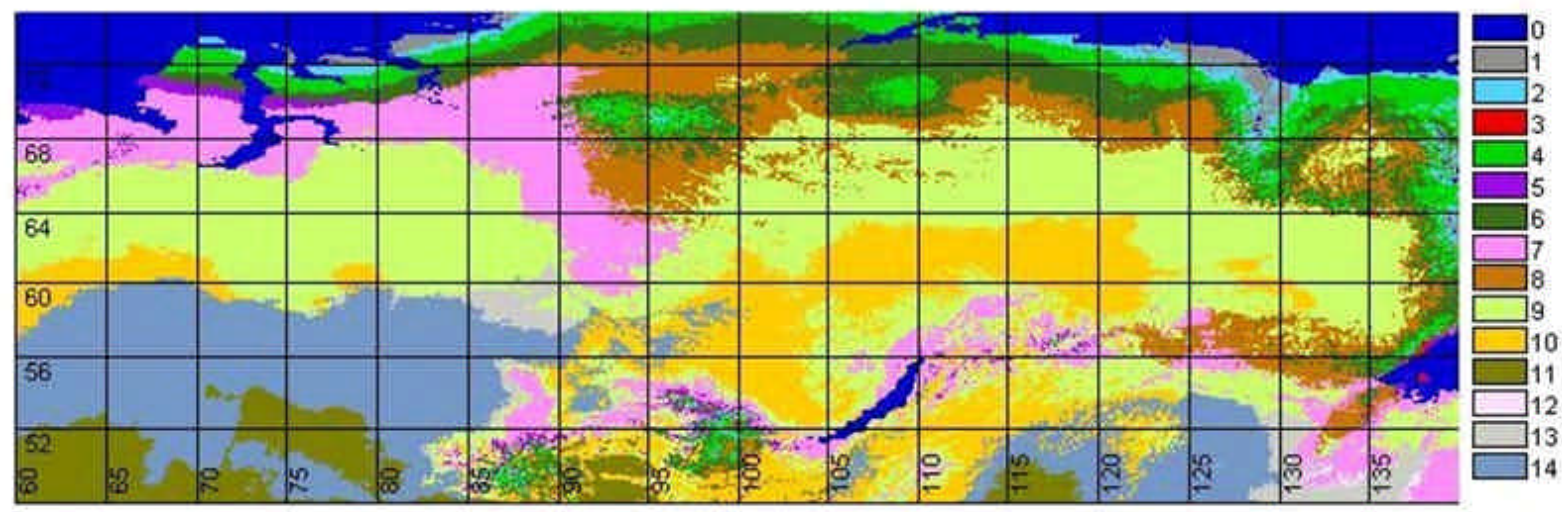

B.

Figure 9.

Vegetation distribution in Siberia: (A) current and (B) future (2100) based on a Hadley scenario (HadCM3GGal) (IPCC, 1996). Water (0), tundra (1), forest-tundra (2), northern dark taiga (3) and light taiga (4), middle dark taiga (5) and light taiga (6), southern dark taiga (7) and light taiga (8), forest-steppe (9), steppe (10), semidesert (11), broadleaved (12), temperate forest-steppe (13) and temperate steppe (14). 

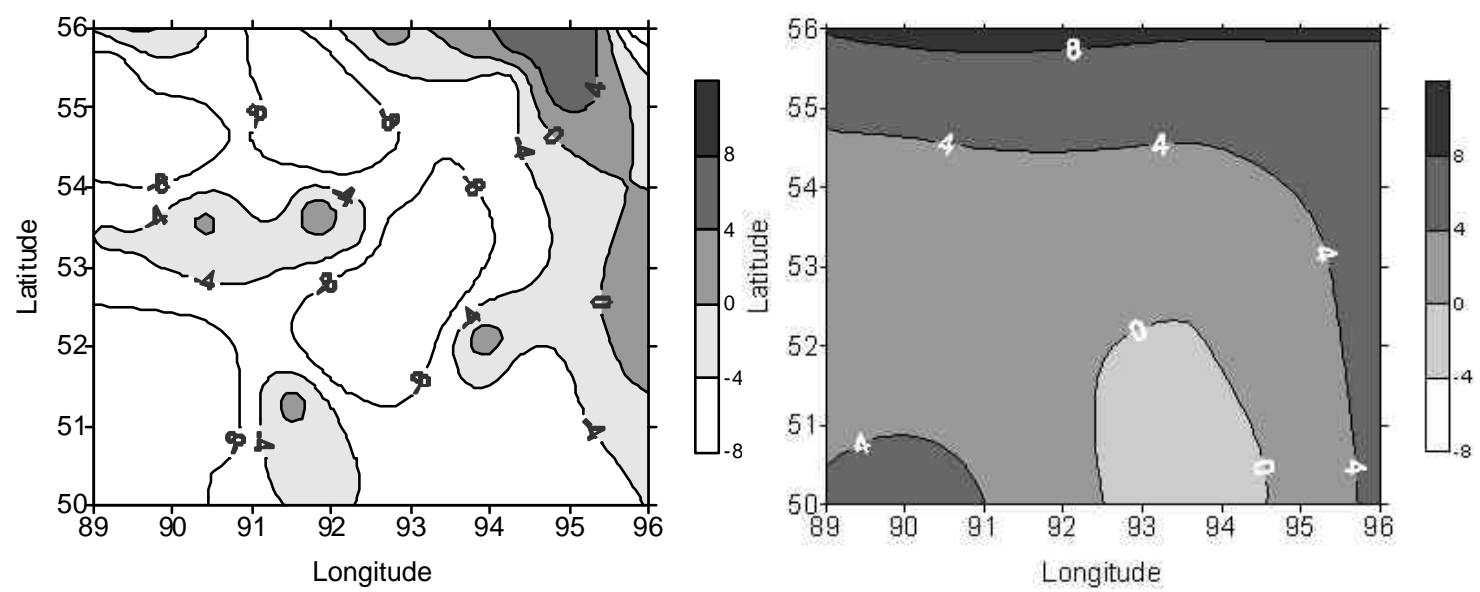

Annual precipitation (\%)
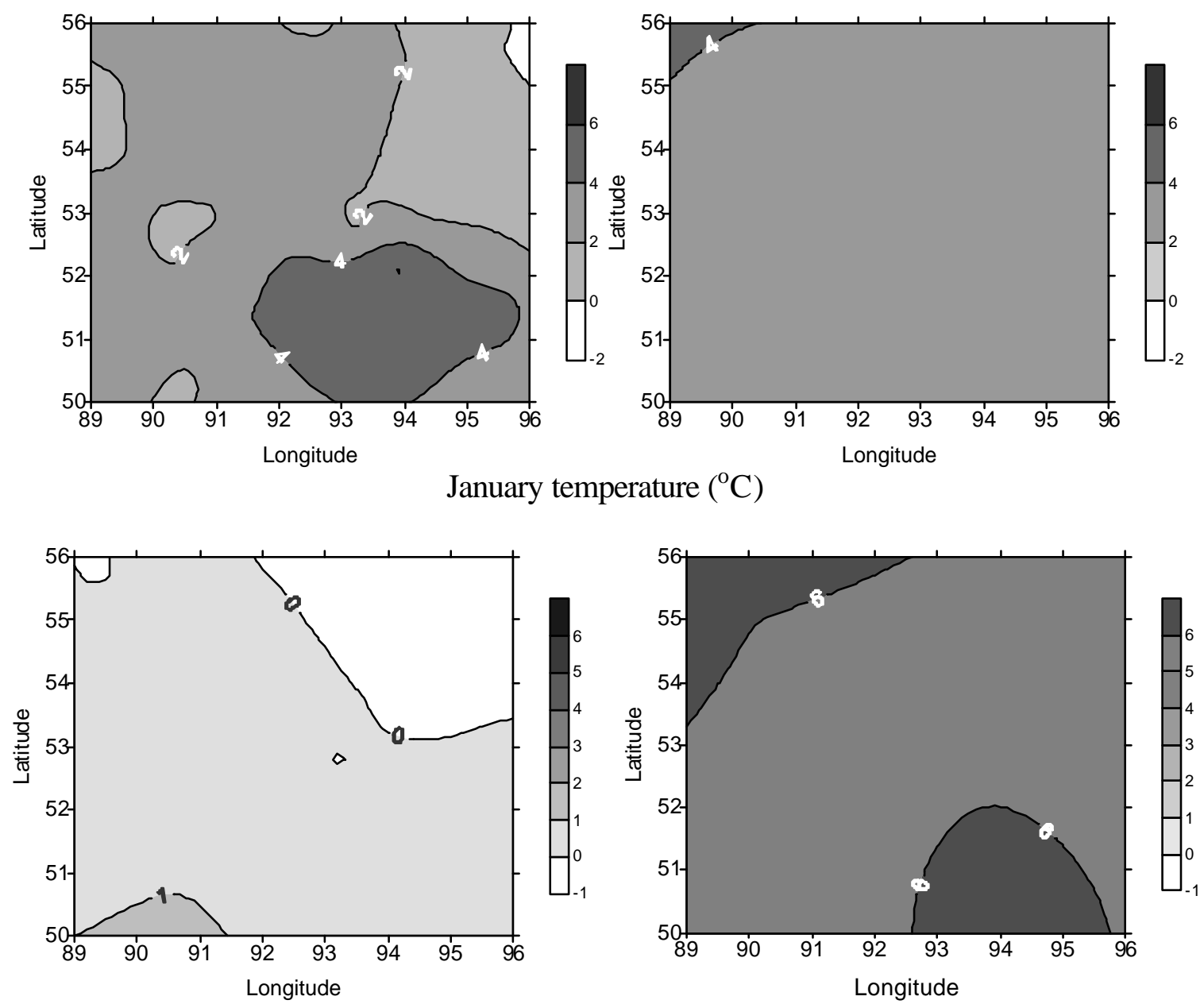

July temperature $\left({ }^{\mathrm{o}} \mathrm{C}\right)$

Figure10. Climate change over the Sayan Mountains: observations from 1980-2000 (left) and predicted (right) by a Hadley Centre scenario (HadCM3GGa1) for 2090. Winter temperatures have already exceeded 2090 model estimates, while summer temperatures have not. Patterns of precipitation are currently difficult to predict, particularly at the GCM scale. 


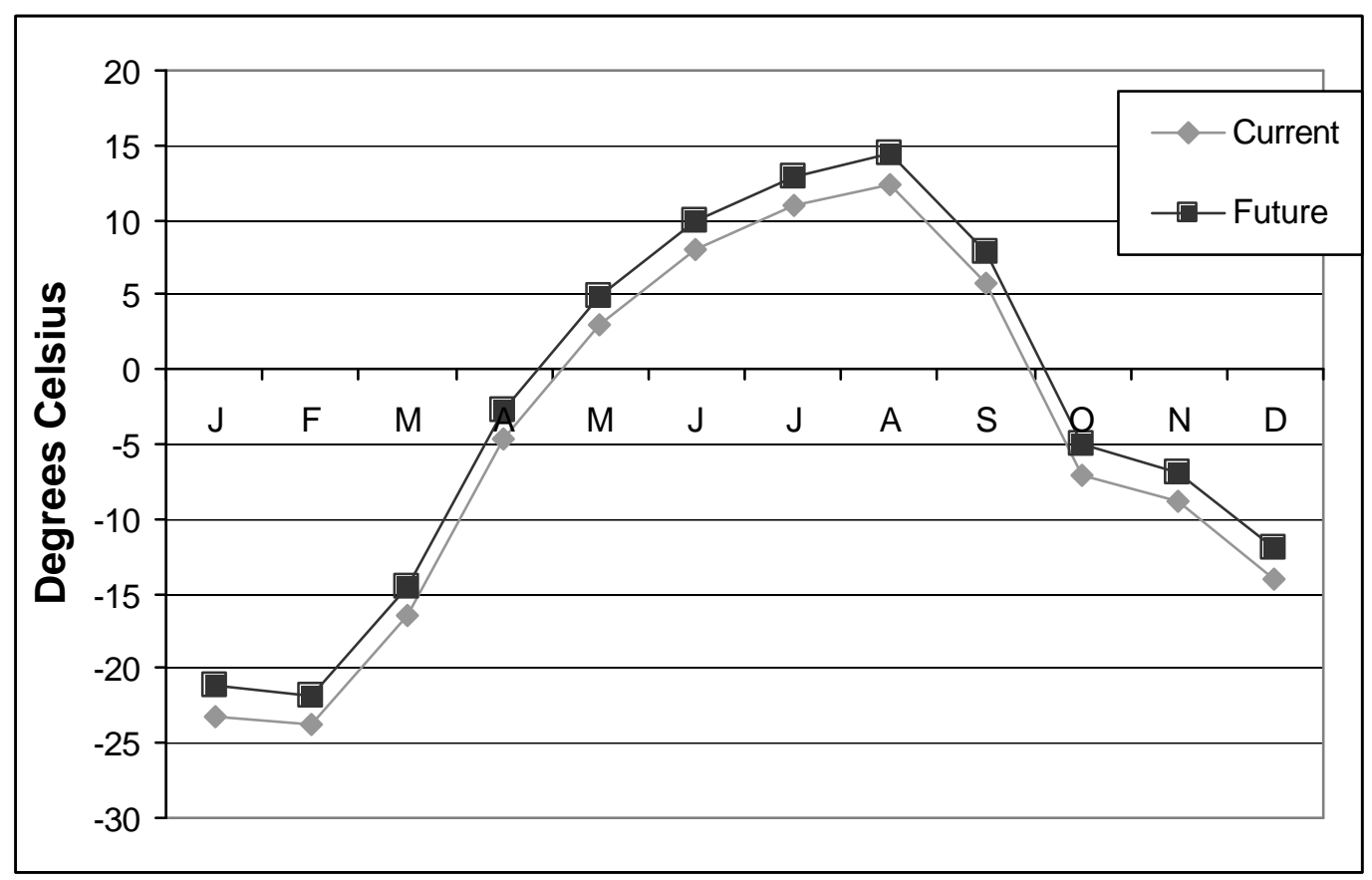

Figure 11

Mean monthly temperatures recorded from the Davsha, Siberia station and projected mean monthly temperatures from a $2^{\circ} \mathrm{C}$ warmer scenario. Monthly temperatures cross the $5^{\circ} \mathrm{C}$ threshold twice, once in the spring and once in the fall. The warm days between these dates are used to determine long-term Growing Season length (GS). Even though GS is a function of temperature in all months, the GS can be approximated using January minimum and July maximum temperatures (positive degree days, L, defined in Table 1) or using the slope of the line, which results in an extension of the GS by 17.44 and 16.45 days, respectively, in this example. 


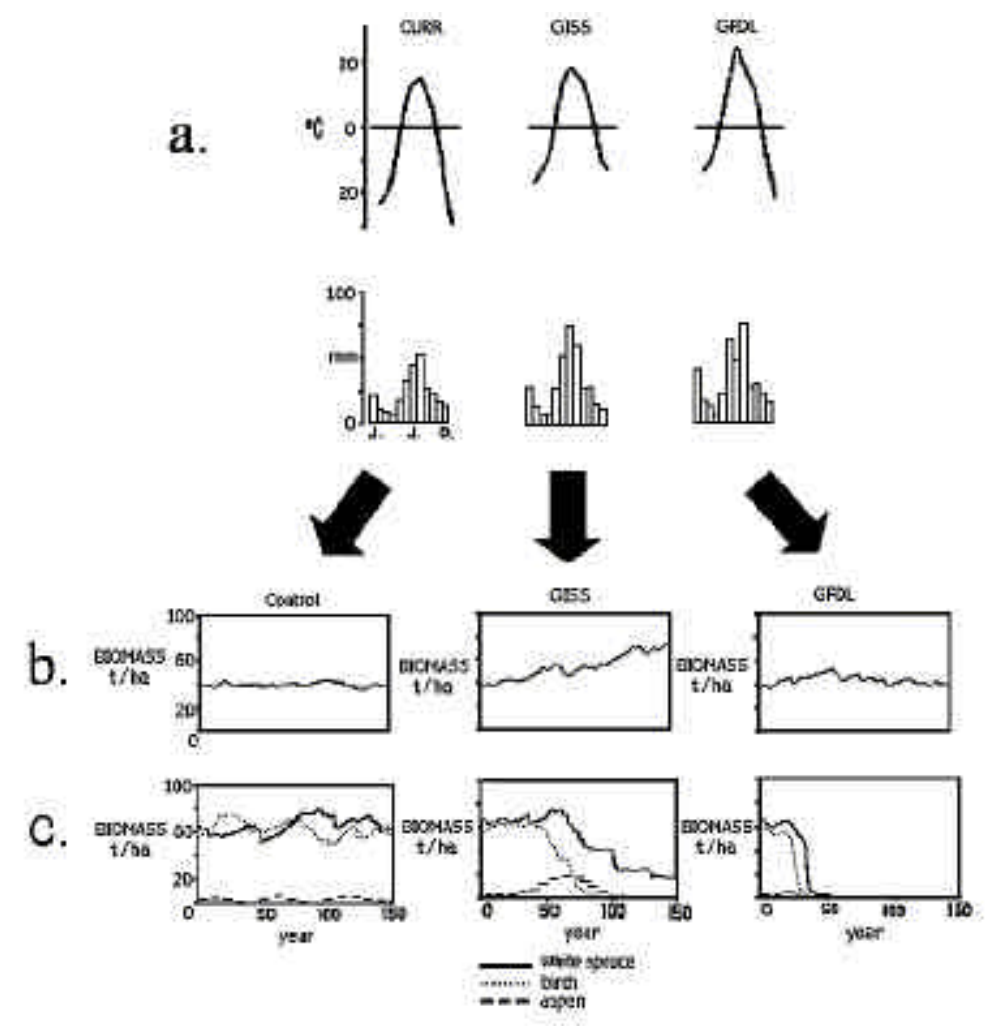

Figure 12

Application of a gap model to predict the dynamic response of forests associated with the current climate and two different climate change scenarios for forests growing in the vicinity of Fairbanks, Alaska. a. The monthly temperature and precipitation for Fairbanks and equivalent information from the GISS (Hansen et al., 1988) and GFDL (Manabe and Wetherald, 1987) climate simulation models. Note the elevated winter temperatures in both models. b. Control case is the average of 100 gap models simulations for forest change over 150 years on north-facing slopes. The transition from the current climate to the new climate occurred incrementally over the first 50 years in the GISS and GFDL cases. The only tree species that occurs in these conditions is Black Spruce (Picea marina). The effect of the transition to a warmer $\mathrm{CO}_{2}$-effect climate is to slightly increase or have no effect on the simulated Black Spruce forest. c. Average of 100 gap model simulations of forest change over 150 years on south-facing slopes. The three species that normally occur in these settings (control case) are eliminated from these sites with climate warming. [Modified from Bonan (1988)]. 